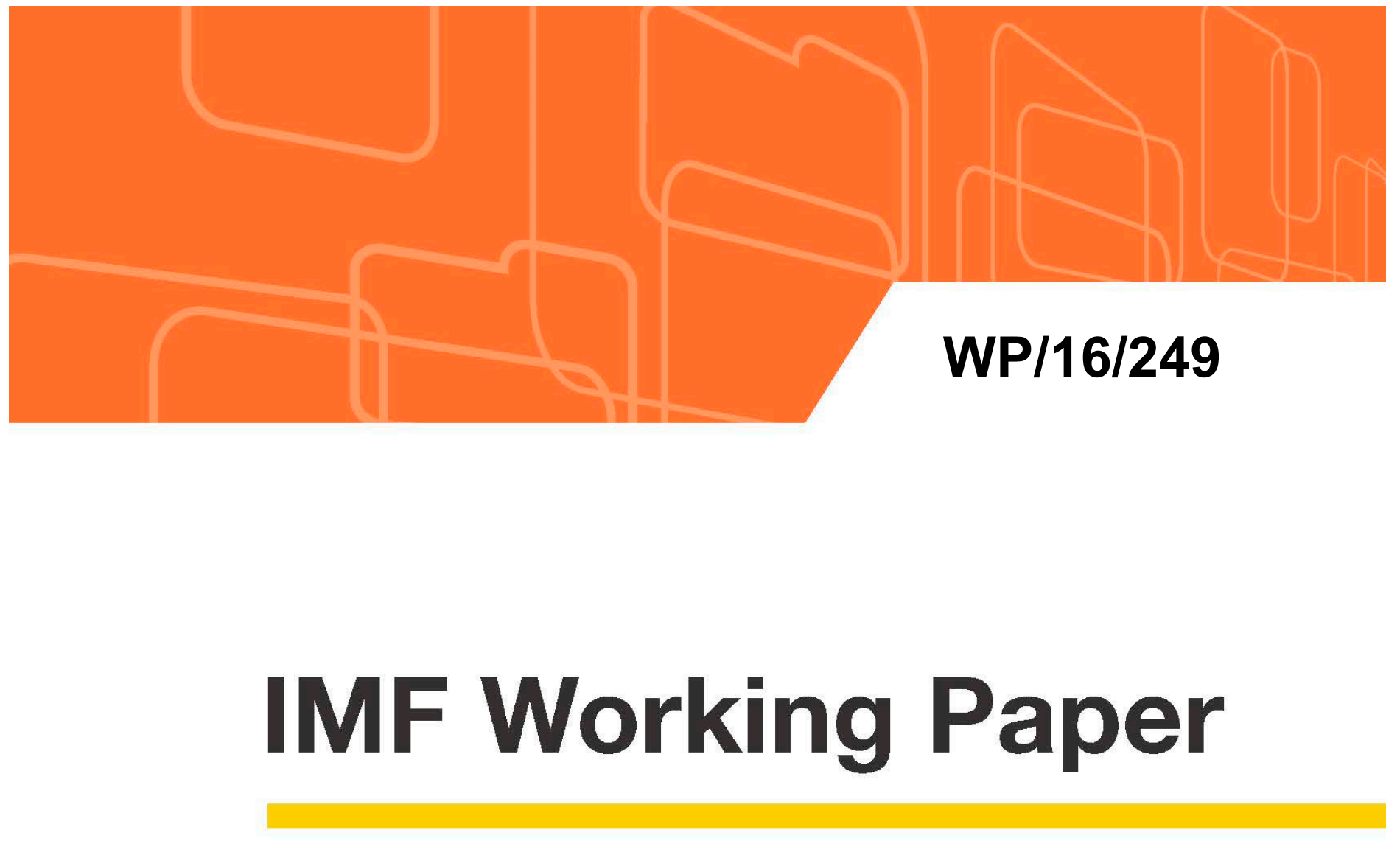

\title{
China's Rising IQ (Innovation Quotient) and Growth: Firm-level Evidence
}

by Jing Fang, Hui He, and Nan Li

IMF Working Papers describe research in progress by the author(s) and are published to elicit comments and to encourage debate. The views expressed in IMF Working Papers are those of the author(s) and do not necessarily represent the views of the IMF, its Executive Board, or IMF management.

$$
\text { I N T E R N A T I O N A L M O N E T A R Y F U N D }
$$




\title{
IMF Working Paper
}

\author{
Research Department
}

\section{China's Rising IQ (Innovation Quotient) and Growth: Firm-level Evidence}

\author{
Prepared by Jing Fang, Hui He, and Nan $\mathrm{Li}^{1}$ \\ Authorized for distribution by Luis Cubeddu
}

December 2016

\begin{abstract}
IMF Working Papers describe research in progress by the author(s) and are published to elicit comments and to encourage debate. The views expressed in IMF Working Papers are those of the author(s) and do not necessarily represent the views of the IMF, its Executive Board, or IMF management.
\end{abstract}

\begin{abstract}
This paper examines whether the rapid growing firm patenting activity in China is associated with real economic outcome by building a unique dataset uniting detailed firm balance sheet information with firm patent data for the period of 1998-2007. We find strong evidence that within-firm increases in patent stock are associated with increases in firm size, exports, and more interestingly, total factor productivity and new product revenue share. Event studies using first-time patentees as the treatment group and non-patenting firms selected based on Propensity-Score Matching method as the control group also demonstrate similar effects following initial patent application. We also find that although state-owned enterprises (SOEs) on average have lower level of productivity and are less innovative compared to their non-state-owned peers, increases in patent stock tend to be associated with higher productivity growth among SOEs, especially for patents with lower innovative content. The latter could reflect the preferential government policies enjoyed by SOEs.
\end{abstract}

JEL Classification Numbers: F43 L60 O31 O33 O43 O53 P31

Keywords: Innovation, Growth, Patent, R\&D, Productivity, SOE Reforms, China Authors’ E-Mail Addresses: bayeswhu@gmail.com; hhe@,imf.org; nli@imf.org

\footnotetext{
${ }^{1}$ We thank Luis Cubeddu, Daniel Garcia-Macia, Zheng Liu, Jianhuan Xu, Xiaodong Zhu, and participants from China Economics Annual 2015 and seminar in Wuhan University for helpful discussions and comments. We are grateful for Hanya Li for excellent research assistance. Hui He thanks research support by Shanghai Pujiang Program, and the Program for Professor of Special Appointment (Eastern Scholar) funded by Shanghai City Government.
} 
I. Introduction

II. Institutional Background, Data and Measurement

A. China's Patent System

B. Data Description

C. Measurement

III. Patent Stock and Firm Performance

A. Determinants of Patenting Behavior 18

B. Within-firm Change in Patent Stock and Firm Performance 20

C. Robustness: Different Types of Patents

D. First-time Patenting Firms

IV. The Role of Financial Constraint

V. The Role of State Ownership 29

A. Patenting Behavior and Firm Production: SOEs versus POEs ___ 29

B. The Impact of SOE Reform

C. SOEs and Innovation Quality 33

VI. Conclusion 35

References

Figures

1. Invention-Patent Applications and R\&D Expenditure in China 3

2. Histogram of Patent Stock and Patent Scope

3. Patent Applications and R\&D Intensity per Firm: SOE vs. POE

4. State Ownership, Financial Constraint and Subsidies

5. State Ownership and Competition (Herfindahl Index)

Tables

1. Matching SIE Data and Patent Data

2. Economic and Innovation Activity of Patenting Firms By Industry

3. Determinants of Patent Stock, Negative Binomial Model

4. Patenting Firms vs. Nonpatenting Firms

5. Patent Stock, Patent Scope and Firm Production Performance

6. Patent Stock, Patent Scope and Firm Production Performance: Different Patent Types

7. First-time Patenting Firms: An Event Study

8. First-time Patenting Firms: Short-run vs. Long-run

9. Patent and Firm Performance: The Role of Financial Constraint 28

10. Patenting and Production Performance: SOEs vs. POEs ___ 31

11. SOEs vs. POEs: Sample Selection

12. The Role of SOE Reform

Appendices

A. Constructing Firm-Specific Markups

B. The Analysis of Propensity-Score Matching 


\section{Introduction}

The last two decades witnessed the astonishing growth in China's innovation input and output. R\&D spending increased by 22 percent per year during 1998-2013, reaching 190 billion USD in 2013. Innovation output, measured by the number of domestic applications for invention patents, rose dramatically from 36 thousand in 1998 to 825 thousand in 2013, surpassing Japan and the United States in 2011 (Figure I) ${ }^{1}$. Accompanying the rising innovation performance is China's spectacular growth, which many attribute to productivity improvement. Zhu (2012), for example, finds that total factor productivity growth has contributed to about $80 \%$ of China's per capita GDP growth.

The soaring number of patents held by Chinese firms (such as Huawei, Lenovo), the rapid accumulation of R\&D stock and the success of large internet and telecom companies (such as Alibaba) have lead some to conclude that China has leapfrogged to the world innovation frontier. Sceptics, on the other hand, contend that China's rising patent filings are simply a response to ambitious government-set target. Without proper intellectual property rights and under the dominance of the inefficient and uninnovative state-owned enterprises (SOEs), many argued the incentive to invent is simply absent. ${ }^{2}$ The quality and real impact of many of these patents are in doubt.

Figure I. Invention-patent applications and R\&D expenditure in China

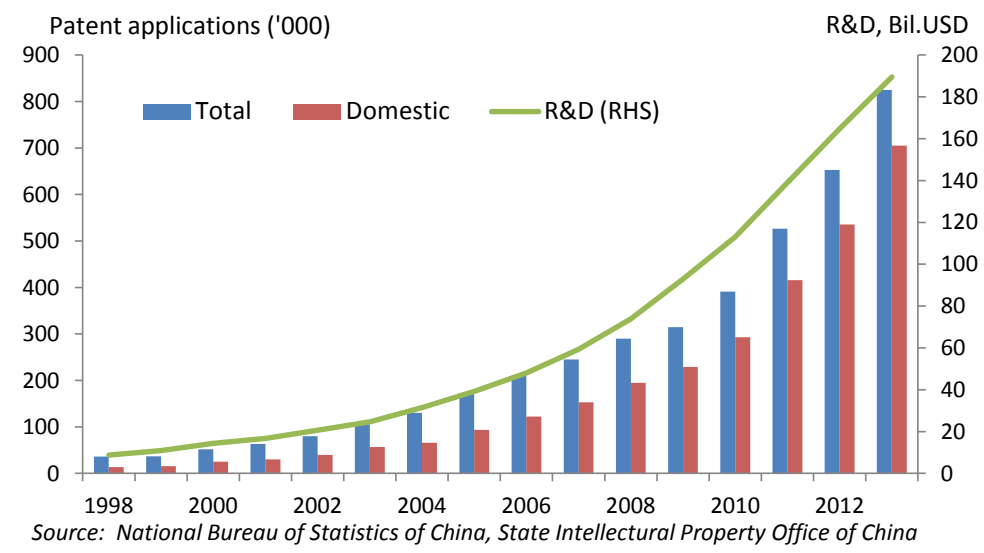

Is technology advancement associated with real TFP growth in China ${ }^{3}$ This paper attempts to inform the answer by examining at the micro level whether Chinese firm patenting is associated

\footnotetext{
${ }^{1}$ Using the number of patents granted as a ratio of the number of patents applied and the foreign citations of Chinese patents, Wei, Xie and Zhang (2016) argues that this explosion of Chinese patents is not simply an outcome of easy approval or low-quality of patents in China,

${ }^{2}$ See, for example, Thomas Reuters (2014), World Bank (2013).

${ }^{3}$ Many have argued that part of China's TFP gorwth may not reflect technical progress but rather an outcome of resource reallocation across sectors and across ownership forms (Borensztein and Ostry (1996)).
} 
with real improvement in firm TFP and other production performance. As patents in developed economies are often used to characterize firm-level innovation and R\&D success (e.g. Hall, Jaffe and Trajtenberg (2005, 2001), Bloom and Van Reenen (2002), Jaffe (1986), Grilches (1981)), such a study also helps us to understand what aspects of economic activity China's patent statistics actually capture, and how it is compared with evidence in industrialized countries. In addition, we investigate which factors determine firms' patenting behavior in China and whether the patenting behavior of state-owned innovating firms is different from that of their the private-owned peers.

This paper makes the first attempt to answer these questions by building a unified dataset combining firm patenting data from China's State Intellectual Property Office (SIPO) and firm production and balance sheet data from China's Surveys of Industrial Enterprises (SIE). Using information of firm name, address and phone number, we develop an annual link between patent assignees and firms in the SIE. The constructed data cover more than 260 thousand firms and almost 1.5 million firm-year observations from 1998 to 2007, representing the majority of nonindividual, nonresearch-instititution and nongovernment assignees during this period.

In line with previous findings using data from industrialized countries, we find that the distribution of patent activities across Chinese firms (both in terms of patent stock and scope) is highly skewed. Only $9.08 \%$ of all firms in the merged data applied for patent, accounting for $37.86 \%$ in terms of value added, $42.13 \%$ in terms of capital stock and $27.39 \%$ in terms of employment. Among these patenting firms, $5.77 \%$ of them engage in innovation in multiple areas, counting for $90.82 \%$ percent of overall patents. Patenting firms are in general significantly larger than nonpatenting firms in size. They also tend to be older, have higher capital-to-labor ratio and higher share of new products in their revenue. But their level of productivity is not necessarily higher. Patenting behavior is also highly heterogeneous across industries. For example, the Computers industry has highest number of patents per firm, which is 20 times more than that of the least innovative industry-processing of foods. Medical industry is the one with highest fraction (36\%) of firms engaging in patenting.

Based on a negative binomial specification of patent determination, we find that younger firms and firms with higher R\&D investment and larger size patent more. SOEs tend to file for less patents than POEs while exporting firms are more innovative than domestic firms. Firms that are new to patenting innovate less. Lastly, financial constraints (measured by firm-specific leverage ratio) tend to have a negative effect on firm patenting decision.

We then examine the within-firm elasticity of firm production performance to changes in patent 
stock (total number of existing patent applications) and patent scope (total number of distinct technological fields in which the firm has applied for patent). Similar to previous studies using U.S. firm patenting data (Balasubramanian and Sivadasan (2011)), we find strong evidence that within-firm changes in patent stock (and scope) is significantly and positively associated with changes in many outcome variables such as size (output, value added, capital stock and employment), productivities measured by various approaches, new product revenue share and export shipment, but no changes in factor intensity or markup. The elasticities of firm size (ranging from 0.13 to $0.15 \log$ points) are of comparable magnitude as these in the U.S. Somewhat surprisingly, the elasticities of productivity $(0.018,0.014,0.051,0.028 \mathrm{log}$ points for labor productivity, Solow Residual, an OLS firm fixed-effects estimate of TFP, and the Ackerberg, Caves, and Frazer (2015) measure of TFP, respectively) are higher and more significant than observed in the U.S. data. The elasticity of new product revenue share is almost $2 \%$ and significant, implying innovation is also associated with introducing new products in China. Within-firm increases in patent scope have even stronger association with firm-level real economic outcomes. Although firm entry and exit are definitely an important phenomenon in a fast growing economy like China and often have far reaching implications, considering only the surviving firms using a balanced panel does not alter our findings, and the estimated elasticities are even larger. These findings also hold across different patent types (invention patent, utility model patent and design patent), although the elasticities are often the highest for utility model patents.

Corroborating with these findings, we observe significant real economic changes associated with a change in patenting status. In a before-and-after study, we find that firms experience significant increase in their sizes, capital stock per work, productivities, new product share and exports, but fall in markup, after applying for patent for the first time. In a difference-in-difference analysis, when using first-time patentees as the treatment group and non-patenting firms selected based on Propensity-Score Matching (PSM) method as the control group, we find similar changes (except for the capital-labor ratio) that coincides with the first-time patenting event. This positive impact of initial patent application, however, does not seem to be long-lasting.

Detailed firm-level data provide an opportunity to also understand the role of various factors that may contribute to the positive relationship between patent activity and a firm's production performance. In this paper, we investigate whether the financial constraint faced by the firm (as proxied by leverage ratios and sales) and its ownership status play any significant role. We find that as expected the financial constraint has a significant negative effect on the elasticity of productivity 
with respect to patent stock: relatively less constrained firms tend to associate a given count of new patent with a higher firm-level productivity growth.

The ownership status of a firm is often an important element in understanding its performance in China, as evidenced in many influential studies on China's economy (Hsieh and Song (2015), Chang, Chen, Waggoner and Zha (2015), Zhu (2012), Song, Storesletten and Zilibotti (2011)). Contrary to the popular perception, the aforementioned positive association between patent application and performance is found to be in fact stronger for SOEs than for their private-owned counterparts. When examining the sample at a finer level, we find that this observation is robust to various choices of sample selection - balanced or unbalanced panel of firms, firms that have kept or changed ownership status. However, when we divide patents into different types (as a proxy for quality), it is evident that SOEs are particularly better at associating patents with lower innovative content with productivity growth.

Related Literature The practice of using patent data in a large scale for economic research on productivity and innovation goes back to Schmookler (1966), followed by Scherer (1982) and Griliches (1984). Previously reliable patent data were only available in industrialized countries and there have been many attempts to combine patent data with firm production data. Recently, Balasubramanian and Sivadasan (2011) develop a new concordance between the NBER patent Data and U.S. Census microdata to examine what happens when firms patent. Our paper is close to their approach and is the first to use Chinese firm-patent data combination to evaluate firm innovation and its impact on productivity growth in China. We find many similarities in the Chinese data compared with the U.S. experience, but also point out important differences in the following sections.

This paper joins forces in the recent empirical studies on China with microeconomic perspectives (Hsieh and Klenow (2009), Brandt and Zhu (2010), Yu and Zhu (2013)) as a variety of firm-level data were made public or available by purchase. Brandt, Van Biesebroeck and Zhang (2012) was the first to estimate firm-level TFP for China's manufacturing firms and find that TFP growth dominates input accumulation in contributing to output growth for manufacturing sectors. This paper utilizes recently available firm patent data and investigate a further question on whether the surge in patenting behavior has contributed to the observed TFP growth. Drawing upon recent method developed (Ackerberg, Caves and Frazer (2015) which addresses functional dependence issues in Olley and Pakes (1996) and Levinsohn and Petrin (2003)), we extend the Brandt et al. 
(2012) TFP estimates and find that Chinese firm patenting is indeed associated with real economic outcomes. This result supports previous literature that uses patents as meaningful proxies of innovation. In addition, the positive association between patents and productivity growth also validates the existing approach in the literature that in the absence of patent data uses changes in TFP or introduction of new products as measures of Chinese innovation (e.g. Aghion et al. (2015)) Using data on R\&D investment, patent information, Wei, Xie and Zhang (2016) discuss the drivers of China's innovation growth and identify potential resource misallocations in innovation area - as the innovation productivity (the elasticity of patent granted with respect to R\&D input) is higher for private firms than for state-owned enterprises while the latter receive more subsidies from the government.

This paper also contributes to the strand of literature on understanding the consequences of the SOE reforms in China. So far, the literature has provided a mixed view. Li, Liu, and Wang (2015) argue that the SOE reforms in late 1990s have strengthened the monopoly power of SOEs in key upstream industries (e.g., energy, telecommunication, transportation), and China's WTO access in 2001 allowed the upstream monopolized SOEs to extract more rents and thus impeded structural change and depressed GDP growth. In contrast, Hsieh and Song (2015) find that firms that were closed or privatized during the SOE reforms were smaller and had low labor and capital productivity. The surviving SOEs, however, caught up with the POEs after the reform. In fact, their total factor productivity growth was even faster than that of POEs. They find that the SOE reform were responsible for 20 percent of aggregate TFP growth from 1998 to 2007. We bring a new perspective into the debate, which is the impact of SOE reforms on innovation and productivity growth by SOEs versus POEs. Somewhat in line with Hsieh and Song (2015), we find that the reforms allow SOEs to catch up with POEs in terms of TFP, and allow SOEs to better associate innovation with productivity growth. Also using patent data in a recent paper, Fang, Lerner and $\mathrm{Wu}(2016)$ finds that innovation increases after SOE privatization and is larger in cities with strong IPR protection.

The rest of the paper is organized as follows. Section 2 provides an institutional background on China's patent system and describes the data construction and measurement of key variables used in this paper. Section 3 presents evidence on the determinants of patent activity and examines the relationship between changes in firms' patent activity (patent stock, scope and status) and production performance. Section 4 studies the role of financial constraint in determining the impact of innovation on firms' performance. Section 5 investigates the role of state ownership. Finally, 
Section 6 concludes.

\section{Institutional Background, Data and Measurement}

\section{A. China's Patent System}

The China's Patent Law was first introduced in 1984, and has since been amended several times to comply with international standards and to facilitate its development into an innovative economy. China's State Intellectual Property Office (SIPO) grants three types of patents: invention patents, utility model patents, and design patents. Broadly speaking, an invention patent protects technical solutions or improvements relating to products or processes, while the utility model patent covers mostly structures and shapes of mechanical structures, and design patents cover new designs, shapes, patterns, or colors, which are rich in an aesthetic appeal and are fit for industrial application.

An invention patent in China corresponds to the utility patent in the United State. Similar to those required in other major patent offices in the world, applicants of invention patents must submit relevant documents such as a clear and comprehensive description of the invention and reference materials so that an examiner may carry out the "Substantive Examination" of the application (novelty, inventiveness and industrial applicability). ${ }^{4}$ It takes approximately 3 to 5 years for an application to complete prosecution. Once granted, invention patents have a duration of 20 years. 26 percent of total patent applications are submitted for invention patent during our sample period.

Applications for utility model patents (similar to a petty patent) are only subject to novelty test and need to have practical use. The requirement for inventiveness in utility model patent is lower than that of invention patent, and thus it can be obtained as quickly as within 12 months after filing. It is preferred for structural products that have a relatively short product life or have a relatively low technology hurdle (i.e. competitors may easily reverse engineer or copy the technology). The term of the utility model patent in China is 10 years from the application date. In contrast, invention patent provides twice the duration of protection and is more useful for products that require a long development time or will be commercially valuable for a long time (i.e. pharmaceutical and biotech).

The design patent application does not require "Substantive Examination" and is only subject

\footnotetext{
${ }^{4}$ Novelty, in particular means that, before the date of filing, no identical invention or utility model has been publicly disclosed in publications or has been publicly used or made known to the public anywhere in the world. Furthermore, there should be no other earlier-filed Chinese applications, which describe the identical invention or utility model even if the publication date thereof is after the date of filing of the present case.
} 
to a formality examination. The patented design must be distinctly different from existing designs or the combinations of the features of existing designs and must not be in conflict with the lawful rights acquired by others prior to the date of application. Time from filing generally varies between 3 and 8 months. A design patent can be granted up to 10 years. Design applications accounted for the largest share of patent applications, 43 percent in our sample.

China today is one of the most litigious country in the world when it comes to intellectual property enforcement. In 2001, only 1,597 infringement actions had been filed. By 2010, that number had risen to 5,700, compared with 3,605 patent infringement actions filed in the United States in the same year.

\section{B. Data Description}

The patent application data are obtained from China's National Bureau of Statistics (NBS). The data cover the universe of approved patents from 1985 until 2011 and contain detailed information (e.g., application number, filing, publishing and granting dates, title, technological class, assignee, inventor, and patent agency) of each patent. The information we use in this paper is patent ID, patent title and its associated International Patent Classification (IPC), and the name (assignee) and address of the applicant (usually a firm or an institution).

Firm-level data come from China's Surveys of Industrial Enterprises (SIE), conducted by China's NBS from 1998 to 2007 annually. It is the most comprehensive firm-level dataset in China and has been widely used in the literature (e.g., Hsieh and Klenow (2009), Brandt, Biesebroeck and Zhang (2012), Aghion et al. (2015), Hsieh and Song (2015)) and is described in detail in Du, Harrison and Jefferson (2012). The survey covers all "above-scale" firms - state-owned (SOEs) and nonstateowned firms with annual revenue of above 5 million RMB (approx. 0.7mil USD) - in the industrial sector including mining, manufacturing and public utilities. Although the data do not include all firms (especially small firms), Brandt et al (2012) show that these firms account for most economic activity in China. Most firm-level production variables (such as output, value added, sales etc) in the dataset sum up almost perfectly to the corresponding aggregate variables in the Chinese Statistical Yearbook.

The SIE data were cleaned following the procedures outlined in Brandt et al. (2012). To construct the panel of firms, we first use a firm's unique registration ID to match the firm over time. For the firm that cannot be matched directly by its ID (probably as a result of merger, acquisition or restructuring), its name, address, telephone number, etc, are used to match it over 
time. ${ }^{5}$ By doing so, we end up with a 10-year unbalanced panel of firms. To handle other potential mismeasurement issues, we drop the following observations from our sample: (i) observations with missing key variables such as total assets, net value of fixed assets, sales, value-added; (ii) firms with reported sales below 5 million RMB (mainly SOEs); and (iii) firms with less than 10 employees. In addition, following Cai and Liu (2009) and guided by the generally accepted accounting principles, we delete observations if any of the following rules is violated: (i) total assets must be higher than current assets; (ii) total assets must be larger than total fixed assets; (iii) total assets must be larger than net value of the fixed assets; and (iv) the established time must be valid. In addition, since our analysis relies on panel techniques, firms with less than four consecutive years of data are also removed. This leaves a final sample of 263,111 firms for the merged sample period of 1998-2007. The overall panel is unbalanced as we keep new entrants and exiters in the sample. Results using balanced panel are sometimes reported in the following sections for comparison.

We then create a comprehensive firm-patent matched dataset that links the patent data to firm data from the SIE. Since the two datasets use different firm identification systems, we manually match them by firm name (i.e. "firm name" in SIE data and "assignee name" in patent data), and verify the match by their location information ("provincial proxy number"). Among all the matched firms in our SIE sample, 29,284 firms applied for patent at least once since the patent law establishment in China-we call these firms "patenting firms" or "patentees". Firms that had no patents at all before the end of our sample period (2007) are labeled as "nonpatenting firms" or "nonpatentees". In total, the matched production-patent data contain 198,414 firm-year observations from 1998 to 2007. As shown in Table I, about $2 \%$ of firms in our SIE sample applied for patents in 1998, accounting for $7 \%$ of the total applications that year. The percentage of firms filing for patents in the SIE sample increased to about $3.4 \%$ by the end of the sample in 2007 . Similar trend is observed in the share of matched patents in total nation-wide patent applications, rising from $7 \%$ in 1998 to $16.5 \%$ in 2007 . Two factors contribute to the low representation of SIE firms in patent data: (a) majority of patents in China are filed by educational and research institutions that are not linked to firms; and (b) the firms included in the SIE are all "above-scale" firms. Since most innovating firms are large firms, the second factor may not be as important. To assess the quality of our match at aggregate, we compare the number of patent applications by "large and medium-sized" industrial firms summarized by NBS China Statistical Yearbook (the last

\footnotetext{
${ }^{5}$ About $95 \%$ of firms from 1998 to 2007 are identified by the registration IDs, while the remainders are matched based on other information.
} 
Table I. Matching SIE Data and Patent Data

\begin{tabular}{|c|c|c|c|c|c|c|c|c|}
\hline \multirow[b]{2}{*}{ Year } & \multicolumn{7}{|c|}{ Our Sample } & \multirow{2}{*}{$\begin{array}{r}\text { NBS CSY } \\
\text { Patents by } \\
\text { large-median } \\
(8)\end{array}$} \\
\hline & $\begin{array}{r}\text { No. of } \\
\text { Firms } \\
(1)\end{array}$ & $\begin{array}{r}\text { No. of patent- } \\
\text { filing firms } \\
(2)\end{array}$ & $(3)=\frac{(2)}{(1)}$ & $\begin{array}{r}\text { No. of } \\
\text { Patentees } \\
(4)\end{array}$ & $\begin{array}{r}\text { Total } \\
\text { Patents } \\
(5)\end{array}$ & $\begin{array}{r}\text { Patents by } \\
\text { matched firms } \\
(6)\end{array}$ & $(7)=\frac{(6)}{(5)}$ & \\
\hline 1998 & 100,126 & 1,981 & 1.98 & 15,945 & 91,014 & 6,638 & 7.29 & 6,317 \\
\hline 1999 & 106,312 & 2,507 & 2.36 & 17,924 & 125,996 & 9,693 & 7.69 & 7,884 \\
\hline 2000 & 106,236 & 2,875 & 2.71 & 18,912 & 132,160 & 11,509 & 8.71 & 11,819 \\
\hline 2001 & 121,884 & 3,475 & 2.85 & 21,970 & 151,184 & 14,728 & 9.74 & 15,339 \\
\hline 2002 & 133,919 & 4,287 & 3.20 & 24,445 & 173,164 & 22,208 & 12.82 & 21,297 \\
\hline 2003 & 155,725 & 5,196 & 3.34 & 27,698 & 220,019 & 29,092 & 13.22 & 31,382 \\
\hline 2004 & 234,522 & 6,511 & 2.78 & 37,772 & 236,928 & 37,820 & 15.96 & 42,318 \\
\hline 2005 & 233,505 & 7,015 & 3.00 & 37,668 & 316,984 & 46,608 & 14.70 & 55,271 \\
\hline 2006 & 262,263 & 8,814 & 3.36 & 40,539 & 368,536 & 66,423 & 18.02 & 69,009 \\
\hline 2007 & 298,152 & 10,152 & 3.41 & 43,858 & 485,399 & 80,270 & 16.54 & 95,905 \\
\hline
\end{tabular}

column) to the number of patent applications in our matched data (Column (6)). The numbers are close, especially considering the trends. This shows that our matched data are representative in terms of capturing patents by "large and medium-sized" industrial firms.

We first report some basic statistics about firms innovation and production distribution across two-digit industries in China. Table II presents the economic and innovation activity of patenting firms by industry. Columns (1) and (2) show the importance of these firms. Although the proportion of firms within each industry that apply for a patent is small, ranging from $2 \%$ to $36 \%$ (Column (1)), they account for a relatively large share of value-added of the industry, ranging from $10 \%$ to $80 \%$, (Column (2)). This is consistent with the stylized facts documented in previous studies using industrial country observations: relatively few firms own patents, but they are large firms that dominate the economic activity. There is also large heterogeneity across industries: $36 \%$ of firms in Medical sector apply for at least one patent in a given year while only $2 \%$ of firms in Apparel, Footwear and caps are patent-owning firms. Among the 29 two-digit industries, Computers, Electrical Machinery and Transport Equipment are the top 3 most innovative industries, both in terms of aggregate innovation output (industry total number of patent applications in Column (3)) and innovation input (industry-level annual R\&D expenditure in Column (4)). As industries also differ in firm concentration, the top 3 industries that boast highest number of patents per firm are slightly different from the previous list: Computers, Manufacturing of articles for Culture Education and Sports and Pressing of Ferrous Metals. Column (8) shows the share of SOE firms in each industry. There is no apparent relationship between the dominance of SOE in the industry and innovation at the industry level. 
Table II. Economic and Innovation Activity of Patenting Firms By Industry

\begin{tabular}{|c|c|c|c|c|c|c|c|}
\hline CIC & Manufacturing Industry & $\begin{array}{r}\% \text { of } \\
\text { Firms } \\
(1)\end{array}$ & $\begin{array}{r}\% \text { of value } \\
\text { Added } \\
(2)\end{array}$ & Patents & $\begin{array}{r}\text { R\&D } \\
(\text { Mil.RMB) } \\
(4)\end{array}$ & $\begin{array}{r}\text { Patents } \\
\text { per Firm } \\
(5)\end{array}$ & $\begin{array}{r}\% \text { of } \\
\text { SOE } \\
(6)\end{array}$ \\
\hline 13 & Processing of Foods & 5.9 & 17.5 & 302 & 46 & 0.50 & 21.6 \\
\hline 14 & Food & 20.2 & 40.2 & 937 & 104 & 1.27 & 19.8 \\
\hline 15 & Beverage & 21.9 & 52.3 & 727 & 209 & 1.25 & 31.0 \\
\hline 16 & Tobacco & 30.5 & 80.9 & 91 & 166 & 1.53 & 90.9 \\
\hline 17 & Textile & 3.9 & 14.1 & 932 & 224 & 1.51 & 25.9 \\
\hline 18 & Apparel, Footwear and Caps & 2.4 & 10.5 & 390 & 52 & 1.69 & 9.0 \\
\hline 19 & Leather & 4.0 & 10.5 & 200 & 20 & 1.12 & 7.8 \\
\hline 20 & Timber & 5.6 & 13.5 & 185 & 16 & 0.95 & 17.6 \\
\hline 21 & Furniture & 10.7 & 20.2 & 499 & 39 & 1.81 & 5.5 \\
\hline 22 & Papermaking & 4.8 & 22.3 & 153 & 110 & 0.57 & 17.6 \\
\hline 23 & Print, Reproduction of media & 6.1 & 23.3 & 104 & 29 & 0.55 & 23.7 \\
\hline 24 & Articles for Culture, Edu. and Sports & 16.6 & 27.5 & 1,059 & 33 & 2.68 & 6.1 \\
\hline 25 & Petroleum Processing & 8.8 & 43.9 & 107 & 155 & 0.78 & 44.0 \\
\hline 26 & Raw Chemical & 12.0 & 34.1 & 1,282 & 960 & 0.78 & 26.2 \\
\hline 27 & Medical & 36.1 & 60.2 & 1,200 & 745 & 0.86 & 26.7 \\
\hline 28 & Chemical Fibers & 10.4 & 45.4 & 91 & 58 & 0.95 & 35.3 \\
\hline 29 & Rubber & 13.5 & 31.8 & 208 & 134 & 0.70 & 21.7 \\
\hline 30 & Plastics & 10.8 & 20.6 & 696 & 93 & 0.79 & 9.9 \\
\hline 31 & Nonmetallic Mineral & 6.5 & 16.8 & 922 & 192 & 0.93 & 24.5 \\
\hline 32 & Pressing of Ferrous Metals & 5.7 & 61.3 & 581 & 1,198 & 2.46 & 48.1 \\
\hline 33 & Pressing of NonFerrous Metals & 9.1 & 42.3 & 353 & 219 & 1.13 & 37.0 \\
\hline 34 & Metal Products & 13.3 & 27.2 & 1,209 & 216 & 0.95 & 12.6 \\
\hline 35 & General Purpose Mchinery & 18.7 & 42.0 & 2,170 & 945 & 0.82 & 23.6 \\
\hline 36 & Special Purpose Machinery & 28.1 & 50.9 & 2,066 & 849 & 0.95 & 27.9 \\
\hline 37 & Transport Equipment & 18.8 & 54.9 & 2,622 & 2,729 & 1.55 & 33.8 \\
\hline 39 & Electrical Machinery and Equipment & 22.3 & 50.1 & 5,000 & 2,199 & 1.95 & 13.2 \\
\hline 40 & Computers and Other & 23.3 & 48.3 & 6,759 & 4,533 & 3.99 & 22.3 \\
\hline 41 & Instruments & 33.0 & 40.2 & 1,019 & 350 & 1.15 & 23.4 \\
\hline
\end{tabular}




\section{Measurement}

Innovation We use three indicators-patent stock, patent scope and patent status in a given year - to evaluate a firm's innovation outcome. Innovating firms often apply patents in multiple technological categories over time. Let $p_{i, t}^{j}>0$ denote the number of patents filed by firm $i$ in category $j$ in year $t$. The total number of patents applied by the firm in year $t$ is then $P_{t}^{i}=\sum_{j} p_{i, t}^{j}$. Patent stock is the accumulated count of patents the firm has applied up to year $t: S_{i t}=P_{i t}+S_{i, t-1}$. SIPO classifies each patent into one of the six-digit technology-based patent categories. A firm's patent scope, $N_{t}$, is defined as the number of technological categories in which it has filed for patent to date (i.e. the dimension of the vector $\left.\left(p_{i, t}^{j}\right)_{j \in J}\right)$. A firm's patent status becomes one from the year it filed for its first patent; otherwise, its patent status is zero.

Figure II presents the distribution of firms' patent stock $(S)$ and patent scope $(N)$ in 2007 . As one can see the distribution for both stock and scope is highly skewed. Among 29,284 firms with positive patent stock in our matched data, majority of the innovating firm (29.2 percent) have only one patent. A few outliers (about 1.38 percent of firms in the matched dataset) have applied for more than 100 patents.

Figure II. Histogram of patent stock and patent scope
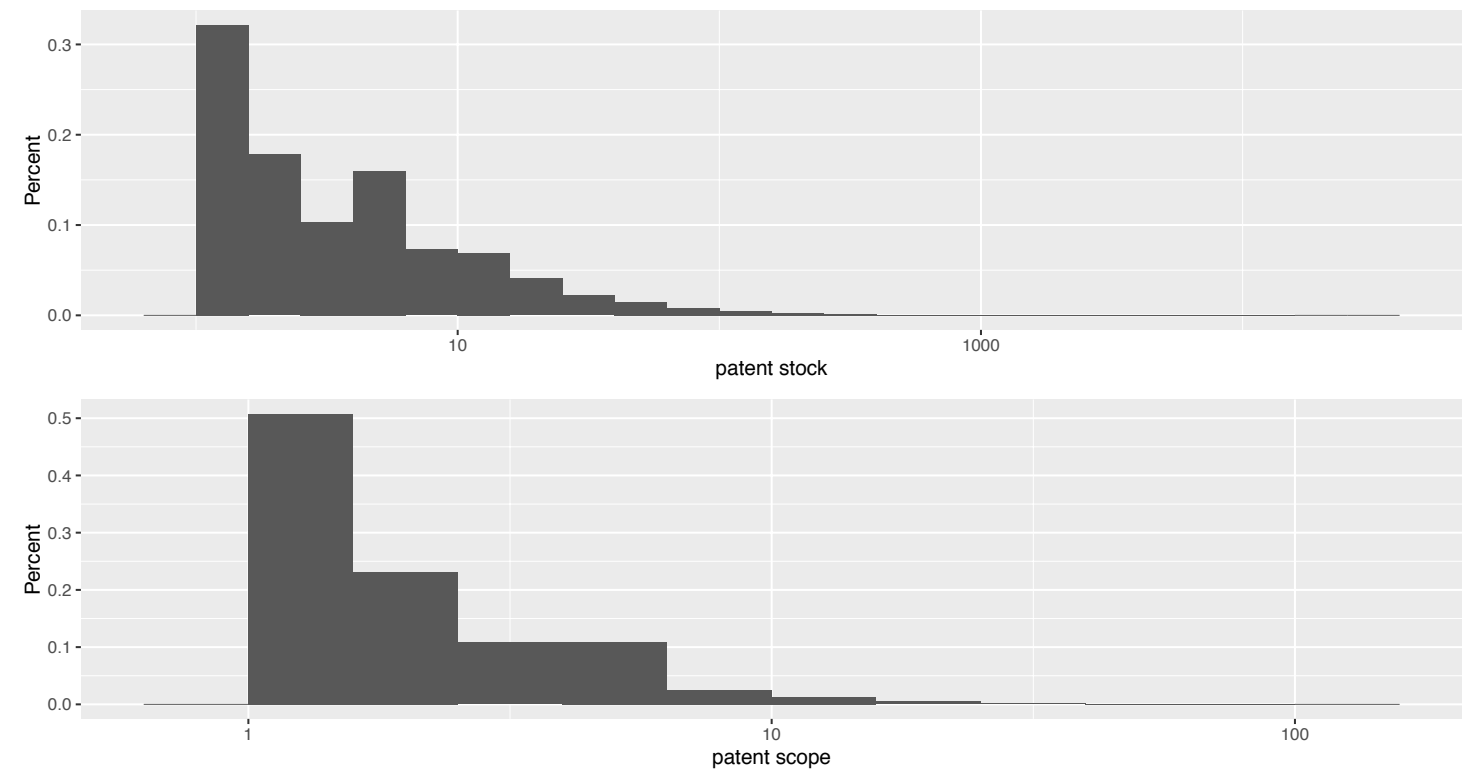

Production The SIE firm-level dataset contains detailed information about firms' balance sheet and income statement. We use data on income statement such as sales, value added, export shipment, employment, capital stock, wage, total intermediate inputs, profits, interest cost to 
evaluate firm performance, as well as constructing TFP of each firm. The balance sheet data on firms' assets and liabilities are useful for measuring firms' credit constraint as well. Since a firm's registration date is also available, we can calculate its age by taking the difference between the current year and the registration year.

Each firm belongs to an industry according to the 4-digit Chinese Industry Classification (CIC) system that resembles the U.S. Standard Industrial Classification (SIC) system. In 2003, the classification system was revised to incorporate more details for some industries, while some other industries were merged. To make the industry codes comparable across the entire period of our sample, we adopt a harmonized classification system created by Brandt et al. (2012) to group industries to a more aggregated level to ensure consistency before and after 2003.

In the SIE, instead of fixed investment, each firm reports the value of fixed capital stock at original purchase prices. These book values are the sum of nominal values from different years, and thus should not be used directly. Following general practice in the literature (e.g., Brandt et al. 2012), we use perpetual inventory method to estimate the real capital stock. We first impute the real initial capital stock of a firm, depending whether it was established before or after 1998the beginning year of our data sample. ${ }^{6}$ We then back out nominal capital stock year by year, by adding annual nominal fixed investment which is the change in nominal capital stock between years, assuming annual depreciation rate of $9 \%$. Finally, we deflate annual investment by investment price deflator developed by Perkins and Rawski (2008).

Another adjustment we made to the data is related to the reported annual employment and wages. The median labor share of value added in our sample is roughly $25 \%$, which is significantly lower than the aggregate labor share in manufacturing sector reported in the Chinese input-output tables and the national accounts (roughly 50\%). Following the procedure suggested by Hsieh and Klenow (2009), in our productivity estimation, we assume that nonwage benefits are a constant fraction of a firm's wage compensation, where the adjustment factor is calculated such that the sum of imputed benefits and wages across all firms equals $50 \%$ of aggregate value added.

Ownership Following Song and Hsieh (2015), we use two variables in SIE data to classify a firm's ownership. First the data provide the share of a firm's registered capital owned by the state, a

\footnotetext{
${ }^{6}$ If a firm in SIE was established after 1998, the initial nominal capital stock is the book value of capital stock that the firm reports first time in SIE data. If a firm was established before 1998, initial capital stock is calculated by using information from the 1993 annual enterprise survey to construct estimates of the average rate of growth of the nominal capital stock between 1993 and the year that this firm appears in SIE first time. The real initial capital stock is then obtained by deflating with the investment deflator in that year.
} 
private person, a collective, a foreigner, and a legal person. A legal person is either another firm or simply a holding company. Second, the data classify the "controlling shareholder" of a firm as the state, a collective, a private person or a foreigner. We define a state owned firm as long as it satisfies the requirement: 1) the registered capital held by the state exceeds $50 \%$ or 2) the "controlling shareholder" for the legal person is the state.

Estimating productivity For robustness and comparability with the literature, productivity is measured in the following four ways. The first measure is the widely used labor productivity, which is calculated as real value added per employee. Given the low labor share in production in China, omitting capital is unlikely to provide an accurate estimate of firm's productivity. In our analysis we thus place greater weight on the other productivity measures. The second measure we consider is the traditional Solow residual. It is constructed as changes in real value added minus factor share weighted sum of changes in capital stock and employment. $\ln T F P_{i t}^{S}=\ln Y_{i t}^{j}-\alpha_{j t} \ln L_{i t}^{j}-(1-$ $\left.\alpha_{j t}\right) \ln K_{i t}^{j}$, where $i$ represents firm and $j$ represents the two-digit industry that the firm belongs to. $Y, L$, and $K$ indicate real value added, employment, and real capital stock in logarithms. Labor share, $\alpha_{j t}$, is then calculated as the share of wage bill in nominal value added of industry $j$. Solow-residual based TFP requires information on the share of factor inputs and can introduce measurement errors. In addition, it assumes perfect competition of both input and output markets; otherwise, the constructed TFP may reflect monopolist rent as it is the residual of real value added after subtracting factor inputs. Thus as a third measure, we follow Bloom and Reenen (2002) and consider the residual from an OLS regression with firm fixed effects of real value added on capital and employment (all in logs).

However, estimating the production function using the OLS-FEs approach does not control for unobserved productivity shocks, which are potentially correlated with inputs and could lead to endogeneity issues. Failing to control for them would cause inconsistent estimates of firm's production function. To deal with this endogeneity issue, we follow the method proposed by Olley and Pakes (1996), Levinsohn and Petrin (2003), and further developed by Ackerberg, Caves and Frazer (2015, ACF hereafter) to handle the functional dependence problem. Specifically, our procedure closely follows De Loecker and Warzynski (2012) and ACF to estimate TFP. To allow for more flexible production function, we consider a translog value added production specification:

$$
y_{i t}=\beta_{k} k_{i t}+\beta_{l} l_{i t}+\beta_{k k} k_{i t}^{2}+\beta_{l l} l_{i t}^{2}+\beta_{k l} k_{i t} l_{i t}+\omega_{i t}+\epsilon_{i t}
$$


where $y_{i t}, k_{i t}, l_{i t}$ are value added, capital and labor of firm $i$ in logarithms, $\omega_{i t}$ is the unobserved productivity shocks, and $\epsilon_{i t}$ is the i.i.d. shocks including measurement errors or unforecastable shocks that are not correlated with inputs $k_{i t}$ and $l_{i t}$. Assume that the demand for material input $m_{i t}$ is decided either at the same time or after $l_{i t}$ is chosen. This implies we can express the material input as:

$$
m_{i t}=f_{t}\left(k_{i t}, l_{i t}, \omega_{i t}\right)
$$

Now assuming strict monotonicity, (2) can be inverted such that $\omega_{i t}=f^{-1}\left(k_{i t}, l_{i t}, m_{i t}\right)$. Substituting this back into the production function, we get

$$
y_{i t}=\beta_{k} k_{i t}+\beta_{l} l_{i t}+\beta_{k k} k_{i t}^{2}+\beta_{l l} l_{i t}^{2}+\beta_{k l} k_{i t} l_{i t}+f_{t}^{-1}\left(k_{i t}, m_{i t}, l_{i t}\right)+\epsilon_{i t}
$$

Treating $f_{t}^{-1}$ non-parametrically, we define the composite term

$$
\Phi_{i t} \equiv \beta_{k} k_{i t}+\beta_{l} l_{i t}+\beta_{k k} k_{i t}^{2}+\beta_{l l} l_{i t}^{2}+\beta_{k l} k_{i t} l_{i t}+f_{t}^{-1}\left(k_{i t}, m_{i t}, l_{i t}\right) .
$$

Employing a third-order polynomial approximation for $f_{t}^{-1}$, we first regress $y_{i t}$ on $m_{i t}, k_{i t}, l_{i t}$ and their higher-order terms according to equation (4), and obtain estimates of the expected value added $\widehat{\Phi}_{i t}$ from the predicted values.

Next, we assume that productivity follows an exogenous first-order Markov process in the form of $\omega_{i t}=g\left(\omega_{i t-1}\right)+\xi_{i t}$. For any given values of $\beta \equiv\left\{\beta_{k}, \beta_{l}, \beta_{k k}, \beta_{l l}, \beta_{k l}\right\}$, we compute the implied $\widehat{\omega}_{i t}$ according to

$$
\widehat{\omega}_{i t}=\widehat{\Phi}_{i t}-\left(\beta_{k} k_{i t}+\beta_{l} l_{i t}+\beta_{k k} k_{i t}^{2}+\beta_{l l} l_{i t}^{2}+\beta_{k l} k_{i t} l_{i t}\right) .
$$

We then regress the $\widehat{\omega}_{i t}$ on the its lag non-parametrically to obtain the implied $\xi_{i t}(\beta)$. Here we employ a second-order polynomial approximation for $g($.$) .$

Based on the assumptions that (a) capital is decided one period ahead and hence does not respond to the current shocks to productivity, and (b) lagged labor is also uncorrelated with the current productivity shocks, we have the following moment conditions: $E\left(\xi_{i t} k_{i t}\right)=0, E\left(\xi_{i t} l_{i t-1}\right)=0$, $E\left(\xi_{i t} k_{i t}^{2}\right)=0, E\left(\xi_{i t} l_{i t-1}^{2}\right)=0$ and $E\left(\xi_{i t} k_{i t} l_{i t-1}\right)=0$. The vector of the production function param- 
eters $\beta$ are then estimated using the standard General Method of Moments (GMM) procedure:

$$
\widehat{\beta}=\arg \min _{\beta} \frac{1}{T} \frac{1}{N} \sum_{t=1}^{T} \sum_{i=1}^{N} \xi_{i t}(\beta)\left(\begin{array}{c}
k_{i t} \\
l_{i t-1} \\
k_{i t}^{2} \\
l_{l t-1}^{2} \\
k_{i t} l_{i t-1}
\end{array}\right)
$$

The above algorithm is applied to every 2-digit industry using data from 1998-2007 to obtain the industry-specific $\widehat{\beta}$. Finally, the TFP of firm $i$ is computed as $\ln T F P_{i t}^{A C F, \text { translog }}=\widehat{\Phi}_{i t}^{j}-\widehat{\beta}_{k} k_{i t}-$ $\widehat{\beta}_{l} l_{i t}-\widehat{\beta}_{k k} k_{i t}^{2}-\widehat{\beta}_{l l} l_{i t}^{2}-\widehat{\beta}_{k l} k_{i t} l_{i t}$.

As a robustness check of our estimation of TFP, we also measure TFP following ACF but using a Cobb-Douglas specification for the production function instead of a generalized translog specification. In this C-D specification estimation, we also employ a third-order polynomial approximation for $f^{-1}$ and a second-order polynomial approximation for $g($.$) . We denote this alternative measure$ as $T F P^{A C F, C D}$ through our analysis.

Estimating markup Lack of individual firm's price index, our TFP measure is calculated based on real value added deflated by the industry-specific price deflator. Since the deflator is common across all firms within the same industry, the observed cross-firm TFP variations may simply reflect differences in the price charged by different firms. For robustness check, we investigate how firmspecific markup changes with patent stock. To uncover firm-level markup, we follow the recent work by De Loecker and Warzynski (2012), which derive the equilibrium markup from firms' cost minimization problem and express markup in terms of output elasticity of input and input share:

$$
m_{i t}=\widehat{\theta}_{i t}^{l}\left(s_{i t}^{l}\right)^{-1}
$$

where $s_{i t}^{l}$ is the expenditure share of labor input, $w_{i t} L_{i t} / P_{i t} Q_{i t}$. With translog production function, the estimated elasticity for labor is given by $\widehat{\theta}_{i t}^{l}=\widehat{\beta}_{l}+2 \widehat{\beta}_{l l} l_{i t}+\widehat{\beta}_{l k} k_{i t}$. See Appendix A for more details on the derivation. 


\section{Patent Stock and Firm Performance}

\section{A. Determinants of Patenting Behavior}

Before evaluating the impact of patents on firms' performance, we first ask what factors account for Chinese firms' patenting behavior. Since the patent count data are highly dispersed across firms, we estimate a version of the Negative Binomial model to analyze the patent count data:

$$
S_{i t}=\exp \left(\alpha_{1} D_{i t} \ln S_{i t-1}+\alpha_{2} D_{i t}+\beta^{\prime} X_{i t-1}+\mu_{i}+\tau_{t}+\varepsilon_{i, t}\right)
$$

where $S_{i t}$ is the patent stock of firm $i$, i.e. a count of the number of patents that firm $i$ has applied for up to time $t$. Following Bloom, Schankerman and Van Reenen (2013), we control for both dynamics and fixed effects by adopting a Multiplicative Feedback Model. $D_{i t}$ is a dummy variable that equals one when total patent applications for firm $i$ at year $t-1, P_{i t-1}>0$, and zero otherwise. ${ }^{7}$ The vector $X_{i t}$ stands for other control variables, including the log of the R\&D expenditure (when available), sales, age, dummies for exporting firms, dummies for SOEs and dummies for firms who are new to patenting (defined as firms whose first patent application is less five years old), as well as a variable proxying financial constraints (leverage ratio). Leverage ratio is measured by the ratio of total liabilities to total assets. A higher leverage ratio indicates that the firm is less financially constrained. Lagged observations for $X_{i t}$ are included to mitigate endogeneity issues. Time dummies, and industry dummies are also controlled for. We also use the "pre-sample mean scaling" method, as in Blundell et al. (1999), to control for firm fixed effects in some of the panel regressions. ${ }^{8}$ Unfortunately, R\&D expenditure data are only available for three years in the SIE: 2001, 2005 and 2006. We are thus unable to construct firm-level R\&D stock and unable to control for $\mathrm{R} \& \mathrm{D}$ in the panel regression.

Table III presents both the cross-section regression estimates using 2007 patent stock as the dependent variable and the panel regression estimates using the entire sample period. Based on cross-section estimation results in Panel A, R\&D investment contributes positively and significantly to patents. Compared to other firms in the same industry, firms with higher sales have more patents,

\footnotetext{
${ }^{7}$ The variance of the Negative Binomial is $\exp \left(x^{\prime} \beta\right)+\alpha \exp \left(2 x_{i t}^{\prime} \beta\right)$, allowing for the variance to be larger than the mean ( $\alpha$ is the over-dispersion measure). This relaxes the restrictions imposed by Poisson regression (i.e. $\alpha=0$ ). Given that the unconditional mean of patent count is much lower than its variance, Negative Binomial Model is more appropriate than the Poisson Model. In addition, we find that estimations based on a Poisson model yield qualitatively similar results and thus do not report them here.

${ }^{8}$ As discussed in Blundell et al (1999), this method relaxes the strict exogeneity assumption required by the approach of Hausman, Hall and Griliches (1984).
} 
Table III. Determinants of Patent Stock, Negative Binomial Model

\begin{tabular}{|c|c|c|c|c|c|c|}
\hline \multirow[t]{2}{*}{ Dept. Var. } & \multicolumn{2}{|c|}{$\begin{array}{l}\text { A. Cross-section (2007) } \\
S_{2007}\end{array}$} & \multicolumn{4}{|c|}{$\begin{array}{c}\text { B. Panel (1998-2007) } \\
S_{t}\end{array}$} \\
\hline & $(1)$ & $(2)$ & (3) & (4) & $(5)$ & $(6)$ \\
\hline $\begin{array}{l}\ln R \& D_{t-1} \\
\text { (s.e.) }\end{array}$ & $\begin{array}{c}0.054^{* * *} \\
{[0.002]}\end{array}$ & $\begin{array}{c}0.054^{* * *} \\
{[0.002]}\end{array}$ & - & - & - & - \\
\hline $\begin{array}{l}\ln \text { sales }_{t-1} \\
\text { (s.e.) }\end{array}$ & $\begin{array}{c}0.375^{* * *} \\
{[0.006]}\end{array}$ & $\begin{array}{c}0.375^{* * *} \\
{[0.006]}\end{array}$ & $\begin{array}{c}0.413^{* * *} \\
{[0.002]}\end{array}$ & $\begin{array}{c}0.095^{* * *} \\
{[0.001]}\end{array}$ & $\begin{array}{c}0.090^{* * *} \\
{[0.001]}\end{array}$ & $\begin{array}{c}0.089^{* * *} \\
{[0.001]}\end{array}$ \\
\hline $\begin{array}{l}\text { age } \\
\text { (s.e.) }\end{array}$ & $\begin{array}{c}-0.004^{* * *} \\
{[0.001]}\end{array}$ & $\begin{array}{c}-0.004^{* * *} \\
{[0.001]}\end{array}$ & $\begin{array}{c}-0.006^{* * *} \\
{[0.000]}\end{array}$ & $\begin{array}{c}-0.003^{* * *} \\
{[0.000]}\end{array}$ & $\begin{array}{c}-0.002^{* * *} \\
{[0.000]}\end{array}$ & $\begin{array}{c}-0.001^{* * *} \\
{[0.000]}\end{array}$ \\
\hline$D_{t}^{S O E}$ & $-0.068^{* * *}$ & $-0.068^{* * *}$ & $-0.110^{* * *}$ & $-0.020 * * *$ & -0.001 & -0.004 \\
\hline (s.e.) & {$[0.025]$} & {$[0.025]$} & {$[0.009]$} & {$[0.005]$} & {$[0.005]$} & {$[0.005]$} \\
\hline$D_{t}^{E X}$ & $0.239^{* * *}$ & $0.238^{* * *}$ & $0.251^{* * *}$ & $0.042^{* * *}$ & $0.039 * * *$ & $0.038^{* * *}$ \\
\hline (s.e.) & {$[0.017]$} & {$[0.017]$} & {$[0.007]$} & {$[0.004]$} & {$[0.004]$} & {$[0.004]$} \\
\hline$D_{t}^{N e w}$ & $-0.214^{* * *}$ & $-0.214^{* * *}$ & $-0.175^{* * *}$ & $0.090 * * *$ & $0.075^{* * *}$ & $0.077^{* * *}$ \\
\hline (s.e.) & {$[0.021]$} & {$[0.021]$} & {$[0.008]$} & {$[0.005]$} & {$[0.005]$} & {$[0.005]$} \\
\hline $\begin{array}{l}\text { Leverage }_{t-1} \\
\text { (s.e.) }\end{array}$ & & $\begin{array}{c}-0.02 \\
{[0.030]}\end{array}$ & & & & $\begin{array}{c}-0.019^{* * *} \\
{[0.007]}\end{array}$ \\
\hline $\begin{array}{l}\ln S_{t-1} \\
\text { (s.e.) }\end{array}$ & & & & $\begin{array}{c}0.857^{* * *} \\
{[0.001]}\end{array}$ & $\begin{array}{c}0.860^{* * *} \\
{[0.002]}\end{array}$ & $\begin{array}{c}0.862^{* * *} \\
{[0.002]}\end{array}$ \\
\hline $\begin{array}{l}\text { Pre-sample FEs } \\
\text { (s.e.) }\end{array}$ & & & & & $\begin{array}{c}0.103^{* * *} \\
{[0.005]}\end{array}$ & $\begin{array}{c}0.099^{* * *} \\
{[0.005]}\end{array}$ \\
\hline Firm FEs & No & No & No & No & Yes & Yes \\
\hline Industry FEs & Yes & Yes & Yes & Yes & Yes & Yes \\
\hline Year FEs & No & No & Yes & Yes & Yes & Yes \\
\hline Number of obs & 195,366 & 195,366 & $1,460,537$ & $1,460,537$ & $1,460,537$ & $1,460,537$ \\
\hline
\end{tabular}

Notes: Dependent variable is overall patent counts. Estimation is conducted using the Negative Binomial model.

Standard errors (in brackets) allow for serial correlation through clustering by firm. A full set of year dummies, industry dummies are included all panel regressions and industry dummies are included in the cross section regressions. Columns (6) - (8) include the pre-sample mean scaling approach used to estimate fixed effects of firms following Blundell, Griffith, and Van Reenen (1999).

and by design firms recently starting to patent have less. Exporting firms have larger patent stock than nonexporting firms. SOEs have less patent stock than POEs. Finally, the financial constraint does not seem to play a significant role in determining the patenting behavior.

Panel B focuses on within-firm changes in the panel regression. As there is strong persistence in patenting behavior, Column (4)-(6) include a lagged dependent variable, $S_{i, t-1}$. Sales and firm's exporting status retain large and significant coefficients. As a firm ages, it becomes less innovative. Different from the cross-section outcome, once previous patent stock is controlled for, firms who are new to innovation are actually more innovative indicating that the innovation rate is higher for new patenting firms. Naturally when firm fixed effects are controlled for using pre-sample mean approach, the SOE status is no longer significant as few firms change their ownership status. Finally, when financial constraint is relaxed, firms actually patent less. 
Table IV. Patenting Firms vs. Nonpatenting Firms

\begin{tabular}{|c|c|c|c|c|c|}
\hline \multirow[b]{2}{*}{ Variable } & \multicolumn{2}{|c|}{ Nonpatenting Firms } & \multicolumn{2}{|c|}{ Patenting Firms } & \multirow[t]{2}{*}{ Difference } \\
\hline & Mean & $\begin{array}{l}\text { Standard } \\
\text { Deviation }\end{array}$ & Mean & $\begin{array}{l}\text { Standard } \\
\text { Deviation }\end{array}$ & \\
\hline \multicolumn{6}{|l|}{ Size } \\
\hline Output & 265,634 & $1,694,065$ & 66,909 & 452,803 & $198725^{*}$ \\
\hline Value added & 74,104 & 499,630 & 17,381 & 100,343 & $56722^{*}$ \\
\hline Capital Stock & 108,754 & 902,112 & 20,844 & 143,504 & $87910^{*}$ \\
\hline Employment & 690 & 2,494 & 246 & 595 & $444^{*}$ \\
\hline \multicolumn{6}{|l|}{ Age } \\
\hline Age & 14.44 & 14.95 & 9.53 & 10.09 & $4.91^{*}$ \\
\hline \multicolumn{6}{|l|}{ Factor } \\
\hline Capital-labor ratio & 114.34 & 387.31 & 85.12 & 239.31 & $29.22^{*}$ \\
\hline \multicolumn{6}{|l|}{ Productivity } \\
\hline Labor productivity & 364.20 & 657.37 & 361.16 & 876.91 & 3.04 \\
\hline Solow Residual & 2.12 & 1.14 & 2.22 & 1.12 & $-0.1^{*}$ \\
\hline $\mathrm{TFP}^{A C F, C D}$ & 3.40 & 1.04 & 3.58 & 0.94 & $-0.17^{*}$ \\
\hline $\mathrm{TFP}^{A C F, T L}$ & 2.21 & 1.43 & 2.60 & 1.43 & $-0.39 *$ \\
\hline \multicolumn{6}{|l|}{ Other } \\
\hline New product (share) & 9.61 & 22.82 & 2.52 & 12.73 & $7.09^{*}$ \\
\hline Markup & 1.55 & 48.06 & 1.81 & 20.47 & $-0.25^{*}$ \\
\hline Export shipment & 48,511 & 739,047 & 15,683 & 239,913 & $32828^{*}$ \\
\hline Number of obs & \multicolumn{2}{|c|}{198,414} & \multicolumn{2}{|c|}{$1,263,326$} & \\
\hline
\end{tabular}

\section{B. Within-firm Change i n Patent Stock and Firm Performance}

This section examines the relationship between a firm's patent application and the associated changes in its production performance. Table IV presents the group means of various measures of firm performance for patenting firms and nonpatenting firms. A patenting firm is one that is matched with at least one assignee (including those that filed for patent before the sample starting year, 1998). This simple comparison shows that patenting firms in China tend to be much larger compared to nonpatenting firms: output, value added, capital stock and employment are generally larger by a factor of 3-5. They are also older, exhibit higher capital-to-labor ratio, exports more and have significantly higher share of revenue that is associated with new products. However, there is no obvious difference in level of productivity between patenting and nonpatenting firms.

We now examine how changes in patent stock is related to changes in firm performance, based on the following fixed-effect regression specification:

$$
\ln Y_{i t}^{j}=\lambda \ln S_{i t}^{j}+\mu_{i}+\gamma_{j, t}+\varepsilon_{i t}^{j},
$$

where $Y_{i t}^{j}$ is the outcome variables, such as sales and various measures of productivity, as listed in Table IV for firm $i$ in 4-digit industry $j$ at time $t ; S_{i t}^{j}$ is the firm's patent stock. The inclusion of firm 
Table V. Patent Stock, Patent Scope and Firm Production Performance

\begin{tabular}{|c|c|c|c|c|c|c|c|c|c|c|c|c|}
\hline & \multicolumn{6}{|c|}{ Overall Panel } & \multicolumn{6}{|c|}{ Balanced Panel } \\
\hline & \multicolumn{3}{|c|}{ Patent Stock } & \multicolumn{3}{|c|}{ Patent Scope } & \multicolumn{3}{|c|}{ Patent Stock } & \multicolumn{3}{|c|}{ Patent Scope } \\
\hline & $\ln (S)$ & (s.e.) & $R^{2}$ & $\ln (N)$ & (s.e.) & $R^{2}$ & $\ln (S)$ & (s.e.) & $R^{2}$ & $\ln (N)$ & (s.e.) & $R^{2}$ \\
\hline \multicolumn{13}{|l|}{ Size } \\
\hline Output & $0.155^{* * *}$ & {$[0.006]$} & 0.93 & $0.206^{* * *}$ & {$[0.010]$} & 0.93 & $0.159^{* * *}$ & {$[0.019]$} & 0.93 & $0.221^{* * *}$ & {$[0.027]$} & 0.93 \\
\hline Value added & $0.152^{* * *}$ & {$[0.008]$} & 0.87 & $0.200^{* * *}$ & {$[0.011]$} & 0.87 & $0.160^{* * *}$ & {$[0.022]$} & 0.89 & $0.221^{* * *}$ & {$[0.031]$} & 0.89 \\
\hline Capital stock & $0.142^{* * *}$ & {$[0.007]$} & 0.95 & $0.182^{* * *}$ & {$[0.010]$} & 0.95 & $0.137^{* * *}$ & {$[0.018]$} & 0.96 & $0.182^{* * *}$ & {$[0.025]$} & 0.96 \\
\hline Employment & $0.137^{* * *}$ & {$[0.006]$} & 0.93 & $0.182^{* * *}$ & {$[0.009]$} & 0.93 & $0.135^{* * *}$ & {$[0.016]$} & 0.93 & $0.181^{* * *}$ & {$[0.024]$} & 0.92 \\
\hline \multicolumn{13}{|l|}{ Factor intensity } \\
\hline Capital-labor ratio & 0.005 & {$[0.006]$} & 0.86 & 0.000 & {$[0.009]$} & 0.86 & 0.003 & {$[0.016]$} & 0.84 & 0.001 & {$[0.023]$} & 0.84 \\
\hline \multicolumn{13}{|l|}{ Productivity } \\
\hline Labor prod & $0.018^{* * *}$ & {$[0.005]$} & 0.85 & $0.024^{* * *}$ & {$[0.008]$} & 0.85 & 0.025 & {$[0.015]$} & 0.85 & $0.040^{*}$ & {$[0.021]$} & 0.85 \\
\hline Solow Residual & $0.014^{*}$ & {$[0.007]$} & 0.78 & $0.018^{*}$ & {$[0.011]$} & 0.78 & 0.024 & {$[0.015]$} & 0.79 & $0.038^{*}$ & {$[0.022]$} & 0.79 \\
\hline OLS-FE & $0.051^{* * *}$ & {$[0.007]$} & 0.89 & $0.067 * * *$ & {$[0.010]$} & 0.89 & $0.062^{* * *}$ & {$[0.016]$} & 0.91 & $0.089^{* * *}$ & {$[0.023]$} & 0.91 \\
\hline $\mathrm{TFP}^{A C F, C D}$ & $0.020^{* * *}$ & {$[0.005]$} & 0.91 & $0.031^{* * *}$ & {$[0.007]$} & 0.91 & $0.025^{*}$ & {$[0.013]$} & 0.92 & $0.036^{*}$ & {$[0.019]$} & 0.92 \\
\hline $\mathrm{TFP}^{A C F, \text { Translog }}$ & $0.028^{* * *}$ & {$[0.006]$} & 0.94 & $0.041^{* * *}$ & {$[0.008]$} & 0.94 & $0.039^{* * *}$ & {$[0.014]$} & 0.95 & $0.048^{* *}$ & {$[0.019]$} & 0.95 \\
\hline \multicolumn{13}{|l|}{ Other } \\
\hline New product (share) & $1.946^{* * *}$ & {$[0.248]$} & 0.73 & $2.825^{* * *}$ & {$[0.331]$} & 0.73 & $2.921^{* * *}$ & {$[0.571]$} & 0.69 & $4.080^{* * *}$ & {$[0.857]$} & 0.69 \\
\hline Markup & 0.044 & {$[0.113]$} & 0.17 & 0.600 & {$[0.631]$} & 0.17 & 0.44 & {$[0.485]$} & 0.14 & 0.477 & {$[0.538]$} & 0.14 \\
\hline Export shipment & $0.402^{* * *}$ & {$[0.034]$} & 0.85 & $0.577^{* * *}$ & {$[0.049]$} & 0.85 & $0.509^{* * *}$ & {$[0.094]$} & 0.84 & $0.689^{* * *}$ & {$[0.148]$} & 0.84 \\
\hline Number of obs & \multicolumn{6}{|c|}{42,717} & \multicolumn{6}{|c|}{26,310} \\
\hline
\end{tabular}

fixed effects, $\mu_{i}$, controls for time-invariant heterogeneity at the firm level. As every firm is classified into one of the 4-digit SIE industries, industry-year fixed effects, $\gamma_{j, t}$, control for industry-specific shocks or trends that can affect both firm patenting and the dependent variable simultaneously.

For the productivity measures, besides the direct measures listed in Table IV, we also consider the OLS-FE measure of productivity (similar to Bloom and Van Reenen, 2002):

$$
\ln V_{i t}^{j}=\lambda_{1} \ln S_{i t}^{j}+\lambda_{2} \ln K_{i t}^{j}+\lambda_{3} \ln L_{i t}^{j}+\mu_{i}+\gamma_{j, t}+\varepsilon_{i t}^{j},
$$

where $V_{i t}$ is the real value-added of firm $i, K_{i t}^{j}$ is capital stock (constructed in the previous section) and $L_{i t}^{j}$ is employment.

Table V shows that Chinese firm patenting is associated with real, large and statistically significant changes in production and productivity within firms. Except for capital-labor ratio, increase in patent stock and patent scope are both associated with significant increases in all outcome variables under consideration. For example, a $10 \%$ increase in patent stock implies about $1.5 \%$ increase in real output and value added, similar rise in capital and employment and $4 \%$ increase in export value.

More interestingly, all productivity measures point to the same conclusion: patenting is also significantly correlated with increase in firm's productivity. ${ }^{9}$ Our favorite measure of productivity,

\footnotetext{
${ }^{9}$ Note that firm patenting is endogenous. Factors that contribute to more patents can simultaneously drive up firm size and productivity. Unfortunately, valid instruments are not available due to data limitation. Observations
} 


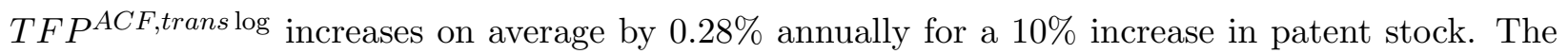
other measures of productivity show similar pattern. TFP $A C F, C D$ increases $0.20 \%$ for a $10 \%$ increase in patent stock. Using OLS-FE measure, $10 \%$ increase in patent stock raises a firm's TFP by $0.51 \%$. And the impact of patent stock on all these TFP measures are significant at $1 \%$ level. This observation is especially striking once compared with similar studies using U.S. firm-level data. Balasuramanian and Sivadasan (2011) report the elasticity of OLS-FE based productivity to changes in patent stock as 0.0152 , about $1 / 3$ of our estimate using the same productivity measure. Their elasticity based on Solow residual is insignificant and is only 0.0035 , again $1 / 3$ of the elasticity estimate found in this study.

Innovations are often associated with creation of new products. We thus also regress the share of new products in total revenue on patent stock controlling for firm fixed effect. As shown in Table $\mathrm{V}$, a $10 \%$ increase in patent stock raises the share of new product by about $19 \%$, suggesting that innovation is reflected in new products development in China. Similarly, when firm's patent scope increases (i.e. firms patented in more sectors), they also become larger, more productive, produce more new products and exports more.

Firm dynamics (entry and exit) could potentially affect the relationship between patenting and production. However, when restricting the sample to only consider firms that operate throughout the whole sample period (as in the Balanced Panel of Table V), we find similar results. Except for the capital-labor ratio, increase in patent stock and patent scope remain to be associated with significant increases in all outcome variables under consideration. And the magnitude of this association is even stronger in the case of productivity.

As mentioned above, due to lack of individual firm's price index, our TFP measure is calculated based on real value added deflated by the industry-specific price deflator. Therefore a legitimate concern is that the variations of TFP measures across firms might simply reflect variations of firmspecific prices. If that is the case, we should expect to see a relationship between estimated markup and patent stock (scope). In Table V, however, we do not find such a significant association between changes in patent stock and changes in markup, which confirms the real association between patent stock and actual TFP measures.

such as R\&D tax subsidies or regulation concerning R\&D only are not available at the firm or industry level. 
Table VI. Patent Stock, Patent Scope and Firm Production Performance: Different Patent Types

\begin{tabular}{|c|c|c|c|c|c|c|}
\hline & \multicolumn{2}{|c|}{ Invention } & \multicolumn{2}{|c|}{ "Utility Model } & \multicolumn{2}{|c|}{ Design } \\
\hline & $\lambda$ & (s.e.) & $\lambda$ & (s.e.) & $\lambda$ & (s.e.) \\
\hline & \multicolumn{6}{|c|}{ Patent Stock } \\
\hline \multicolumn{7}{|l|}{ Size } \\
\hline Output & $0.127 * * *$ & {$[0.015]$} & $0.170 * * *$ & {$[0.008]$} & $0.139 * * *$ & {$[0.010]$} \\
\hline Value added & $0.114^{* * *}$ & {$[0.017]$} & $0.174^{* * *}$ & {$[0.010]$} & $0.129 * * *$ & {$[0.012]$} \\
\hline Capital stock & $0.113^{* * *}$ & {$[0.015]$} & $0.144^{* * *}$ & {$[0.009]$} & $0.137^{* * *}$ & {$[0.010]$} \\
\hline Employment & $0.113^{* * *}$ & {$[0.011]$} & $0.149 * * *$ & [0.008] & $0.131^{* * *}$ & {$[0.011]$} \\
\hline \multicolumn{7}{|l|}{ Factor intensity } \\
\hline Capital-labor ratio & 0.000 & {$[0.014]$} & -0.004 & {$[0.008]$} & 0.007 & {$[0.010]$} \\
\hline \multicolumn{7}{|l|}{ Productivity } \\
\hline Labor productivity & 0.014 & {$[0.012]$} & $0.021 * *$ & {$[0.008]$} & 0.008 & [0.009] \\
\hline Solow Residual & -0.002 & {$[0.015]$} & $0.027^{* * *}$ & {$[0.010]$} & -0.005 & {$[0.012]$} \\
\hline OLS-FE & $0.032^{* *}$ & {$[0.014]$} & $0.066^{* * *}$ & {$[0.009]$} & $0.031^{* * *}$ & {$[0.012]$} \\
\hline $\mathrm{TFP}^{A C F, C D}$ & $0.019 * *$ & {$[0.009]$} & $0.019 * * *$ & {$[0.007]$} & 0.008 & {$[0.008]$} \\
\hline $\mathrm{TFP}^{A C F, \text { Translog }}$ & $0.019^{*}$ & {$[0.010]$} & $0.025^{* * *}$ & {$[0.008]$} & $0.024^{* * *}$ & [0.009] \\
\hline \multicolumn{7}{|l|}{ Other } \\
\hline New product (share) & $2.165^{* * *}$ & [0.639] & $2.566^{* * *}$ & {$[0.282]$} & $0.943^{* * *}$ & [0.353] \\
\hline Markup & 0.006 & {$[0.192]$} & 0.098 & {$[0.192]$} & -0.61 & {$[0.571]$} \\
\hline \multirow[t]{2}{*}{ Export shipment } & $0.318^{* * *}$ & {$[0.073]$} & $0.502^{* * *}$ & {$[0.041]$} & $0.346^{* * *}$ & {$[0.053]$} \\
\hline & \multicolumn{6}{|c|}{ Patent Scope } \\
\hline \multicolumn{7}{|l|}{ Size } \\
\hline Output & $0.186^{* * *}$ & {$[0.020]$} & $0.215^{* * *}$ & {$[0.012]$} & $0.243^{* * *}$ & {$[0.014]$} \\
\hline Value added & $0.173^{* * *}$ & {$[0.025]$} & $0.207^{* * *}$ & {$[0.015]$} & $0.227^{* * *}$ & [0.019] \\
\hline Capital stock & $0.156^{* * *}$ & {$[0.022]$} & $0.190 * * *$ & {$[0.012]$} & $0.206^{* * *}$ & {$[0.017]$} \\
\hline Employment & $0.157^{* * *}$ & {$[0.016]$} & $0.187^{* * *}$ & {$[0.010]$} & $0.220^{* * *}$ & {$[0.014]$} \\
\hline \multicolumn{7}{|l|}{ Factor intensity } \\
\hline Capital-labor ratio & -0.001 & {$[0.021]$} & 0.003 & {$[0.011]$} & -0.014 & [0.018] \\
\hline \multicolumn{7}{|l|}{ Productivity } \\
\hline Labor productivity & $0.029 *$ & {$[0.017]$} & $0.028 * *$ & {$[0.011]$} & $0.023^{*}$ & {$[0.014]$} \\
\hline Solow Residual & 0.012 & {$[0.022]$} & 0.017 & {$[0.014]$} & 0.014 & {$[0.019]$} \\
\hline OLS-FE & $0.059^{* * *}$ & {$[0.021]$} & $0.068^{* * *}$ & {$[0.013]$} & $0.068^{* * *}$ & {$[0.018]$} \\
\hline $\mathrm{TFP}^{A C F, C D}$ & $0.037^{* * *}$ & {$[0.013]$} & $0.035^{* * *}$ & {$[0.010]$} & $0.027^{* *}$ & {$[0.012]$} \\
\hline $\mathrm{TFP}^{A C F, \text { Translog }}$ & $0.037^{* * *}$ & {$[0.013]$} & $0.034^{* * *}$ & {$[0.010]$} & $0.055^{* * *}$ & {$[0.014]$} \\
\hline \multicolumn{7}{|l|}{ Other } \\
\hline New product (share) & $2.936 * * *$ & {$[0.820]$} & $3.105^{* * *}$ & [0.395] & $2.891^{* * *}$ & [0.602] \\
\hline Markup & -0.079 & {$[0.165]$} & 0.062 & {$[0.192]$} & 1.741 & {$[1.792]$} \\
\hline Export shipment & $0.555^{* * *}$ & {$[0.090]$} & $0.662^{* * *}$ & {$[0.062]$} & $0.523^{* * *}$ & {$[0.082]$} \\
\hline
\end{tabular}




\section{Robustness: Different Types of Patents}

Not all patents are created equal. The empirical studies using patent data in industrial countries quantify patent quality by citation data, which however are not available in the Chinese patent dataset. One way to differentiate patents is by their categories. Invention patents generally contain more innovation value as it has to meet the "Substantive Examination", whereas the Utility Model and Design patents stress more their value for practical use. Here we re-estimate (9) and (10) using separate subsamples of these three types of patents. The regression results are presented in Table VI. Increases in all types of patent stock are positively and significantly associated with increases in sizes, productivity, revenue share of new products and exports. However, the magnitude of most elasticities is notably smaller for the most inventive type, i.e. invention patents. Rises in patent scope across all categories are also found to increase with firm performance and there are no significant differences in the coefficients for productivities.

\section{First-time Patenting Firms}

Similar to Balasubramanian and Sivadasan (2011), this section adopts an event study approach to examine what happens to the firm's production performance after it changes its patenting status (i.e. it applies for patents for the first time conditional on it is eventually approved). First, in a before-and-after comparison in equation (11), we only study firms who applied for patents for the first time during our sample period and its own performance before the patenting event as the control group. The estimated coefficient associated with the dummy variable Switch (which equals one in and after the year the firm first applied for a patent) $\varphi$ gives the estimated change in outcome variables associated with first-time patenting.

Second, in a difference-in-difference (DID) specification (12), we examine how outcome variables change after first-time patenting compared to the other similar nonpatenting firms in the same industry. To ensure comparability, each patenting firm is first paired with a nonpatenting firm in the same industry with similar pre-patenting characteristics (age and size) by Propensity-score Matching. ${ }^{10}$ Appendix B explains this matching in more detail. Then the post-patenting changes in production performance of these two groups of firms are compared using the difference-in-difference method. Given that our panel spans just over 10 years, we include only firms that have at least 3-year observations before and after switching from being a nonpatenting firm to a patenting firm.

\footnotetext{
${ }^{10}$ The results are largely unchanged when more than one nonpatenting firms are matched with a given patenting firm as control groups
} 
The magnitude and statistical significance of change in performance after switch are evaluated by estimating the following regressions:

$$
\begin{aligned}
\text { Before-and-After: } Y_{i t}^{j} & =\varphi \text { Switch } \text { it }_{i t}+\mu_{i}+\varepsilon_{i, t}^{j} . \\
\text { Difference-in-Difference: } Y_{i t}^{j} & =\varphi \text { Switch }{ }_{i t}+\mu_{i}+\gamma_{j, t}+\varepsilon_{i, t}^{j} .
\end{aligned}
$$

where Switch $_{i t}=1$ if $t \geq t_{0}$ and $t_{0} \in(1998,2007)$ is the first year that firm $i$ filed for patent.

Panel A in Table VII summarizes the estimates of $\varphi$, which captures the changes that accompany the event, for each outcome variable under the two specifications. Except for capital-labor ratio, $\varphi$ is estimated to be positive and significant (all at $1 \%$ level) positive under both specifications. ${ }^{11}$ In the Before-and-After analysis, the increase in output and value added is in the magnitude of $0.67 \log$ points, while the increases in capital and labor input are smaller (in 0.46 and $0.22 \log$ points). Capital-to-labor ratio also jumps following the first-time patenting event. There are also significant increase in productivity. Specifically based on our favorite measure of TFP using ACF method and translog production specification, we find an increase of 0.4 log points in TFP. Other measures of productivity show even larger increase in magnitude following the switch. In addition, there is about $3 \%$ increase in new product share in total revenue and an increase of 0.96 log points in export value. Interestingly, markup drops significantly after the switch, supporting the view that it is not growing markup that drives the increase in TFP after patenting.

When controlling for sector-specific shocks in the difference-in-difference analysis (equation (12)), the estimated $\varphi$ provides an estimate for the change in patentee production performance relative to changes in nonpatenting firms in the same industry. Estimation results in Panel B confirm findings in Panel A. All measures of performance (except for capital-labor ratio) increase significantly after the switch but the associated estimates of $\varphi$ are much smaller. Compared to the nonpatenting peers in the same industry, first-time patentees experience an increase of $0.17 \log$ points in output and value added, and 0.15 log points in capital and employment. The increase in TFP is still significant but only about $0.04 \mathrm{log}$ points based on TFP $P^{A C F, \text { Translog }}$.

Equations (11) and (12) capture the immediate impact of a firm's patent application on its

\footnotetext{
${ }^{11}$ To test the robustness of the results of equations (11) and (12) to different quality of innovation, we run the regressions for the three different types of patent: invention, utility model and design. The coefficients of all five TFP measures are positive and significant for invention and utility patent. The coefficients of labor productivity and Solow residual of equation (12) are not significant for design patent.
} 
Table VII. First-time Patenting Firms: An Event Study

\begin{tabular}{|c|c|c|c|c|c|c|}
\hline & \multicolumn{3}{|c|}{ A. Before-and-After } & \multicolumn{3}{|c|}{ B. Difference-in-Difference } \\
\hline & $\varphi$ & (s.e.) & $R^{2}$ & $\varphi$ & (s.e.) & $R^{2}$ \\
\hline \multicolumn{7}{|l|}{ Size } \\
\hline Output & $0.664 * * *$ & {$[0.016]$} & 0.87 & $0.176^{* * *}$ & [0.011] & 0.90 \\
\hline Value added & $0.669^{* * *}$ & {$[0.016]$} & 0.80 & $0.170^{* * *}$ & {$[0.014]$} & 0.83 \\
\hline Capital stock & $0.463^{* * *}$ & {$[0.018]$} & 0.91 & $0.148^{* * *}$ & {$[0.012]$} & 0.93 \\
\hline Employment & $0.216^{* * *}$ & {$[0.013]$} & 0.87 & $0.148^{* * *}$ & [0.010] & 0.89 \\
\hline \multicolumn{7}{|l|}{ Factor intensity } \\
\hline Capital-labor ratio & $0.247^{* * *}$ & {$[0.016]$} & 0.79 & 0.000 & {$[0.012]$} & 0.83 \\
\hline \multicolumn{7}{|l|}{ Productivity } \\
\hline Labor productivity & $0.448^{* * *}$ & [0.014] & 0.76 & $0.028^{* * *}$ & {$[0.010]$} & 0.82 \\
\hline Solow Residual & $0.367^{* * *}$ & {$[0.025]$} & 0.63 & $0.024^{* * *}$ & [0.013] & 0.73 \\
\hline OLS-FE & $0.669^{* * *}$ & {$[0.016]$} & 0.80 & $0.170^{* * *}$ & {$[0.014]$} & 0.83 \\
\hline $\mathrm{TFP}^{A C F, C D}$ & $0.439^{* * *}$ & {$[0.013]$} & 0.82 & $0.039^{* * *}$ & {$[0.009]$} & 0.90 \\
\hline $\mathrm{TFP}^{A C F, \text { Translog }}$ & $0.397^{* * *}$ & {$[0.016]$} & 0.85 & $0.043^{* * *}$ & [0.009] & 0.94 \\
\hline \multicolumn{7}{|l|}{ Other } \\
\hline New product (share) & $3.257^{* * *}$ & {$[0.301]$} & 0.61 & $1.673^{* * *}$ & [0.333] & 0.63 \\
\hline Markup & $-0.617^{* *}$ & {$[0.241]$} & 0.12 & $-0.501^{*}$ & {$[0.304]$} & 0.17 \\
\hline Export shipment & $0.961^{* * *}$ & {$[0.066]$} & 0.78 & $0.490^{* * *}$ & [0.061] & 0.82 \\
\hline Number of obs & \multicolumn{3}{|c|}{44,379} & \multicolumn{3}{|c|}{76,964} \\
\hline
\end{tabular}

performance. To further differentiate short run and long run impact, we run the following regression:

$$
Y_{i t}^{j}=\sum_{z=0}^{3} \varphi_{z} S w i t c h_{i t}^{z}+\mu_{i}+\gamma_{j, t}+\varepsilon_{i, t}^{j},
$$

where $S$ witch ${ }_{i t}^{0}=1$ if firm $i$ files a patent application for the first time at year $t$, zero otherwise. Switch $_{i t}^{z}=1$ if firm $j$ files a patent application for the first time at year $t-z$, zero otherwise for $z=1,2,3$. Therefore $\varphi_{0}$ captures the immediate impact of the first time patent application. $\varphi_{1}$ captures the impact of a firm's first time patent application on the following year and $\varphi_{2}$ captures the impact of a firm's first time patent application on the firm's performance in the second year after it starts patenting, and so on.

Table VIII presents estimation results for regression (13). The immediate impact of patenting on outcome variables are all positive and significant at $1 \%$ level (except capital-labor ratio and markup). However, this impact quickly dissipates for most outcome variables after the first year of patenting, and it even turns negative for the second and third years although the coefficients are often insignificant. Therefore, the impact of first-time patenting on a firm's performance is mostly contemporaneous. 
Table VIII. First-time Patenting Firms: Short-run vs. Long-run

\begin{tabular}{|c|c|c|c|c|c|c|c|c|c|}
\hline & $\varphi_{0}$ & (s.e.) & $\varphi_{1}$ & (s.e.) & $\varphi_{2}$ & (s.e.) & $\varphi_{3}$ & (s.e.) & $R^{2}$ \\
\hline \multicolumn{10}{|l|}{ Size } \\
\hline Output & $0.165^{* * *}$ & {$[0.010]$} & $0.029 * * *$ & {$[0.007]$} & $-0.038 * * *$ & {$[0.007]$} & $-0.075^{* * *}$ & {$[0.011]$} & 0.85 \\
\hline Value added & $0.170^{* * *}$ & {$[0.013]$} & $0.024^{* *}$ & {$[0.001]$} & $-0.057 * * *$ & [0.011] & $-0.098^{* * *}$ & {$[0.015]$} & 0.77 \\
\hline Capital stock & $0.139^{* * *}$ & [0.009] & $0.024^{* * *}$ & {$[0.008]$} & $-0.036^{* * *}$ & {$[0.006]$} & $-0.115^{* * *}$ & {$[0.011]$} & 0.91 \\
\hline Employment & $0.130^{* * *}$ & {$[0.009]$} & $0.029 * * *$ & {$[0.006]$} & -0.008 & {$[0.006]$} & $-0.039 * * *$ & {$[0.009]$} & 0.88 \\
\hline \multicolumn{10}{|l|}{ Factor intensity } \\
\hline Capital-labor ratio & 0.009 & {$[0.010]$} & -0.005 & {$[0.009]$} & $-0.028^{* * *}$ & {$[0.008]$} & $-0.076^{* * *}$ & {$[0.009]$} & 0.84 \\
\hline \multicolumn{10}{|l|}{ Productivity } \\
\hline Labor productivity & $0.035^{* * *}$ & {$[0.009]$} & 0.000 & {$[0.007]$} & $-0.031^{* * *}$ & {$[0.007]$} & $-0.036^{* * *}$ & {$[0.009]$} & 0.81 \\
\hline Solow Residual & $0.039 * * *$ & {$[0.012]$} & -0.004 & {$[0.012]$} & $-0.036^{* * *}$ & [0.011] & $-0.030^{* *}$ & {$[0.012]$} & 0.74 \\
\hline OLS-FE & $0.170 * * *$ & {$[0.013]$} & $0.024^{* *}$ & {$[0.011]$} & $-0.057 * * *$ & [0.011] & $-0.098 * * *$ & {$[0.015]$} & 0.77 \\
\hline $\mathrm{TFP}^{A C F, C D}$ & $0.033^{* * *}$ & {$[0.009]$} & $0.010^{*}$ & {$[0.006]$} & -0.007 & {$[0.005]$} & -0.003 & {$[0.008]$} & 0.88 \\
\hline $\mathrm{TFP}^{A C F, \text { Translog }}$ & $0.034^{* * *}$ & {$[0.009]$} & $0.015^{* *}$ & {$[0.006]$} & -0.005 & {$[0.006]$} & 0.007 & {$[0.009]$} & 0.94 \\
\hline \multicolumn{10}{|l|}{ Other } \\
\hline New product (share) & $1.151^{* * *}$ & {$[0.348]$} & 0.440 & {$[0.341]$} & 0.483 & [0.309] & $0.667^{*}$ & {$[0.369]$} & 0.58 \\
\hline Markup & -0.544 & {$[0.376]$} & 0.043 & {$[0.152]$} & -0.073 & {$[0.134]$} & -0.107 & {$[0.125]$} & 0.17 \\
\hline Export shipment & $0.421^{* * *}$ & {$[0.059]$} & 0.039 & {$[0.052]$} & 0.024 & [0.049] & $0.114^{* *}$ & {$[0.058]$} & 0.82 \\
\hline
\end{tabular}

\section{The Role of Financial Constraint}

Although financial constraint (measured by leverage ratio) is not found to have consistent impact on firm patent application (see Table III), this section investigates whether financial constraint plays any role in affecting the positive relationship between changes in patent stock (or scope) and changes in real firm performance. To answer this question, we run the following regression for firm $i$ in industry $j$ at time $t$

$$
\ln Y_{i t}^{j}=\alpha_{1} \ln S_{i t}^{j}+\alpha_{2} F C_{i t-1}^{j}+\alpha_{3} \ln S_{i t}^{j} \times F C_{i t-1}^{j}+\mu_{i}+\gamma_{j, t}+\varepsilon_{i t}^{j},
$$

where $F C_{i, t-1}^{j}$ is the measure of financial constraint that firm $i$ in industry $j$ faces at year $t-1$. The lagged variable is included to mitigate potential endogeneity problem.

The literature (e.g., Farre-Mensa and Ljungqvist, 2013) often finds that financially constrained firms on average are less leveraged and smaller compared with "unconstrained" firms. Motivated by such findings, we use two measures to proxy financial constraint: the leverage ratio (total liability divided by total sales) and sales. More precisely, we include a dummy variable $F C$ in equation (14), which equals one if a firm's leverage ratio (sales) is above the median value across all firms, and zero otherwise.

Table IX reports the regression results based on (14). The dependent variable in Panel A is the leverage ratio and in Panel B the sales. We are most interested in the coefficient $\alpha_{3}$, which indicates the role that the financial constraint plays in relating patents to a firm's production performance. 
We pay special attention to how financial constraint affects the impact of innovation on a firm's TFP. Table IX shows that the coefficients of the interactive terms, $\ln (S) \times F C$, on various measures of TFP, are always significantly positive for both proxies of credit constraint. This finding indicates that less constrained firms tend to associate patenting with a higher level of TFP growth.

Table IX. Patent and Firm Performance: The Role of Financial Constraint

\begin{tabular}{|c|c|c|c|c|c|c|c|}
\hline & \multicolumn{7}{|c|}{$F C=$ Leverage Ratio } \\
\hline & $\alpha_{1}$ & (s.e.) & $\alpha_{2}$ & (s.e.) & $\alpha_{3}$ & (s.e.) & $R^{2}$ \\
\hline \multicolumn{8}{|l|}{ Size } \\
\hline Output & $0.151^{* * *}$ & {$[0.007]$} & $-0.062^{* * *}$ & {$[0.007]$} & 0.006 & {$[0.004]$} & 0.93 \\
\hline Value added & $0.147^{* * *}$ & {$[0.008]$} & $-0.084^{* * *}$ & [0.009] & 0.009 & {$[0.006]$} & 0.87 \\
\hline Capital stock & $0.135^{* * *}$ & {$[0.007]$} & $-0.088^{* * *}$ & {$[0.007]$} & $0.011^{* * *}$ & {$[0.004]$} & 0.96 \\
\hline Employment & $0.140^{* * *}$ & {$[0.006]$} & $-0.035^{* * *}$ & {$[0.006]$} & $-0.007^{*}$ & {$[0.004]$} & 0.93 \\
\hline \multicolumn{8}{|l|}{ Factor intensity } \\
\hline Capital-labor ratio & -0.005 & {$[0.006]$} & $-0.053^{* * *}$ & [0.008] & $0.019^{* * *}$ & {$[0.004]$} & 0.86 \\
\hline \multicolumn{8}{|l|}{ Productivity } \\
\hline Labor productivity & $0.011^{*}$ & {$[0.006]$} & $-0.026^{* * *}$ & {$[0.006]$} & $0.013^{* * *}$ & {$[0.004]$} & 0.85 \\
\hline Solow Residual & 0.009 & {$[0.008]$} & $-0.027 * * *$ & [0.009] & 0.008 & {$[0.005]$} & 0.78 \\
\hline OLS-FE & $0.046^{* * *}$ & {$[0.007]$} & $-0.047^{* * *}$ & [0.008] & $0.011^{* *}$ & {$[0.005]$} & 0.89 \\
\hline$T F P^{A C F, C D}$ & $0.016^{* * *}$ & {$[0.005]$} & -0.007 & {$[0.005]$} & $0.008^{* *}$ & {$[0.003]$} & 0.91 \\
\hline$T F P^{A C F, \text { Translog }}$ & $0.025^{* * *}$ & {$[0.006]$} & -0.001 & {$[0.006]$} & $0.007^{*}$ & {$[0.004]$} & 0.94 \\
\hline \multicolumn{8}{|l|}{ Other } \\
\hline New product (share) & $1.928^{* * *}$ & {$[0.266]$} & -0.37 & {$[0.226]$} & 0.025 & {$[0.170]$} & 0.73 \\
\hline markup & -0.042 & {$[0.218]$} & -0.271 & {$[0.335]$} & 0.168 & {$[0.306]$} & 0.17 \\
\hline \multirow[t]{3}{*}{ Export shipment } & $0.394^{* * *}$ & {$[0.035]$} & $-0.059^{*}$ & [0.033] & 0.014 & {$[0.022]$} & 0.85 \\
\hline & \multicolumn{7}{|c|}{$F C=$ Sales } \\
\hline & $\alpha_{1}$ & (s.e.) & $\alpha_{2}$ & (s.e.) & $\alpha_{3}$ & (s.e.) & $R^{2}$ \\
\hline \multicolumn{8}{|l|}{ Size } \\
\hline Output & $0.104^{* * *}$ & {$[0.008]$} & $0.192^{* * *}$ & {$[0.009]$} & $0.048^{* * *}$ & {$[0.006]$} & 0.928 \\
\hline Value added & $0.114^{* * *}$ & {$[0.010]$} & $0.198^{* * *}$ & {$[0.012]$} & $0.035^{* * *}$ & {$[0.008]$} & 0.871 \\
\hline Capital stock & $0.117^{* * *}$ & {$[0.008]$} & $0.055^{* * *}$ & [0.008] & $0.026^{* * *}$ & {$[0.005]$} & 0.955 \\
\hline Employment & $0.106^{* * *}$ & {$[0.007]$} & $0.114^{* * *}$ & [0.008] & $0.029 * * *$ & {$[0.005]$} & 0.928 \\
\hline \multicolumn{8}{|l|}{ Factor intensity } \\
\hline Capital-labor ratio & 0.011 & {$[0.008]$} & $-0.059 * * *$ & [0.008] & -0.004 & {$[0.006]$} & 0.858 \\
\hline \multicolumn{8}{|l|}{ Productivity } \\
\hline Labor productivity & -0.002 & {$[0.007]$} & $0.079 * * *$ & [0.008] & $0.019^{* * *}$ & {$[0.006]$} & 0.85 \\
\hline Solow Residual & 0.003 & {$[0.009]$} & $0.109^{* * *}$ & {$[0.010]$} & 0.008 & {$[0.007]$} & 0.783 \\
\hline OLS-FE & $0.036^{* * *}$ & {$[0.008]$} & $0.129^{* * *}$ & [0.010] & $0.015^{* *}$ & {$[0.007]$} & 0.888 \\
\hline$T F P^{A C F, C D}$ & 0.002 & {$[0.006]$} & $0.082^{* * *}$ & {$[0.007]$} & $0.017^{* * *}$ & {$[0.005]$} & 0.913 \\
\hline$T F P^{A C F, \text { Translog }}$ & 0.004 & {$[0.007]$} & $0.091^{* * *}$ & {$[0.008]$} & $0.023^{* * *}$ & {$[0.005]$} & 0.943 \\
\hline \multicolumn{8}{|l|}{ Other } \\
\hline New product (share) & $1.549^{* * *}$ & {$[0.289]$} & $0.498^{*}$ & [0.268] & $0.415^{* *}$ & {$[0.190]$} & 0.726 \\
\hline markup & 0.704 & {$[0.540]$} & -0.338 & [0.642] & -0.711 & {$[0.555]$} & 0.17 \\
\hline Export shipment & $0.289^{* * *}$ & {$[0.043]$} & $0.083^{* *}$ & {$[0.036]$} & $0.121^{* * *}$ & {$[0.027]$} & 0.846 \\
\hline
\end{tabular}

Notes: All regressions control for firm and industry-year fixed effects. 


\section{The Role of State Ownership}

\section{A. Patenting Behavior and Firm Production: SOEs versus POEs}

A unique feature of Chinese economy is the prevailing existence of state-owned enterprises (SOEs), which are often viewed as less productive compared to private-owned enterprises (POEs) and not completely driven by profit-maximization purposes (see Song, Storeletten and Zilibotti, 2011). A simple comparison between an average SOE and an average POE (in Figure III) shows that SOEs and POEs filed similar number of patents before 2001 and the former actually surpassed the latter starting from 2001. Part of this observation is explained by more allocation of R\&D resources to SOEs as shown in the same graph. In fact, regression results presented in Table III suggest that SOEs are actually less innovative than POEs once size and R\&D investment are controlled for.

Figure III. Patent Applications and R\&D Intensity per Firm: SOE vs. POE

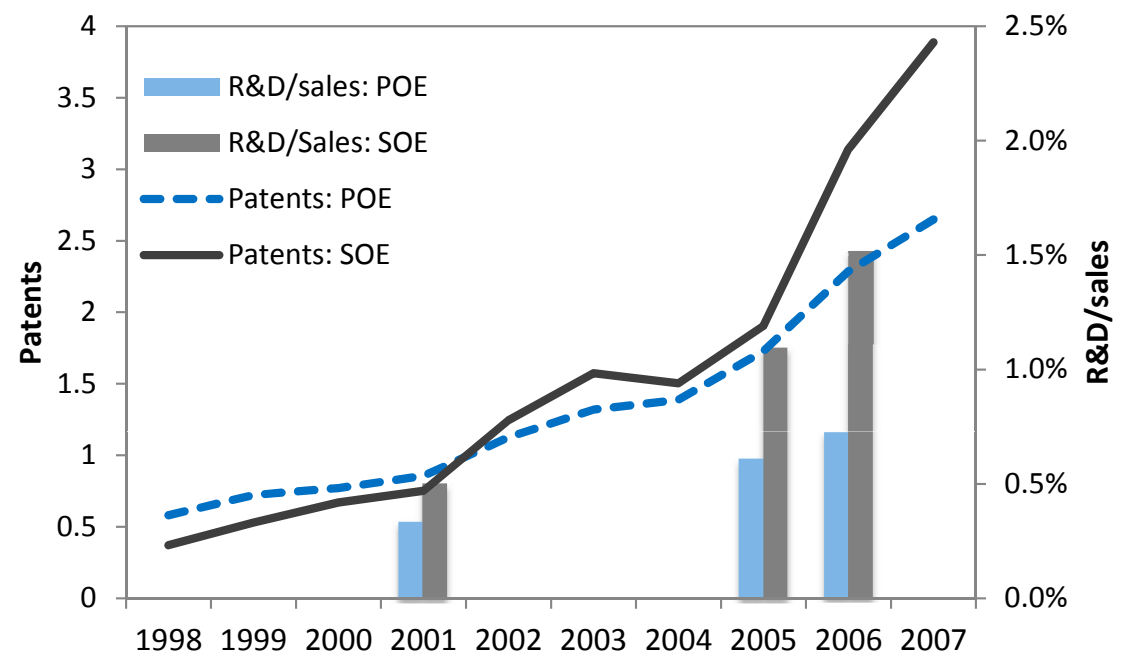

The next question is whether there are any significant differences between SOEs and POEs in terms of the relationship between their patenting behavior and production performance. To answer this question, we run the following regression:

$$
\ln Y_{i t}^{j}=\lambda_{1} \ln S_{i t}^{j}+\lambda_{2} S O E_{i t}^{j}+\lambda_{3} \ln S_{i t}^{j} \times S O E_{i t}^{j}+\mu_{i}+\gamma_{j, t}+\varepsilon_{i t}^{j},
$$

where as before, $Y_{i t}$ denotes the outcome variables listed in Table IV. SOE is a dummy variable taking value to be one if the firm is state-owned and zero otherwise. Parallel to equation (10), we also estimate the OLS-FE measure of TFP by interacting the ownership status with patent stock 
(or scope):

$$
\ln V_{i t}^{j}=\alpha \ln K_{i t}^{j}+\beta \ln L_{i t}^{j}+\lambda_{1} \ln S_{i t}^{j}+\lambda_{2} S O E_{i t}^{j}+\lambda_{3} \ln S_{i t}^{j} \times S O E_{i t}^{j}+\mu_{i}+\gamma_{j, t}+\varepsilon_{i t}^{j} .
$$

Table $\mathrm{X}$ shows the estimation results for equations (15) and (16). We find that as expected SOEs are generally larger and have lower productivity compared to POEs. What is surprising is that the positive correlation between changes in patent stock and changes in productivity is actually higher for SOEs (as suggested by the significantly positive estimates of $\lambda_{3}$ ), suggesting that SOEs are potentially better at adapting new in-house innovation to improve their productivities.

We then investigate if this observation is simply an outcome of sample selection bias. There are two sources of selection bias. First, POEs are generally more dynamic - there are more entry and exit of POEs than those of SOEs. It is possible that some innovative but small POEs may not have survived and were dropped out of the sample. To handle this, we rerun the regression (15) using a balanced panel of surviving firms. Second, our sample period (1998-2007) covers an important period of reform in China - the SOE reform which began in 1997 and gradually phased out after 2002. The economic trouble brought by the unbearably inefficiency of moneylosing SOEs pushed the Chinese government to initiate a large-scale privatization of SOEs in 1997 under the slogan "Grasp the Big, Let Go of the Small". Except for large SOEs in strategic sectors (e.g., energy, electricity, telecommunications, and banking), majority of small-to-medium size SOEs were either privatized or went bankrupt (see Hsieh and Song, 2015 for details). Thus, there is a significant fraction of less productive firms have switched ownership from state-owned to privateowned. ${ }^{12}$ These firms may show up as POEs in the later part of the sample and bias the SOE-POE comparison. To address the selection bias generated by change of the ownership status, we rerun the regression (15) for a more restricted sample that excludes firms that switched ownership over the period 1998-2007. We label the sample as "constant ownership". Finally, to correct for both firm dynamics and ownership switching biases simultaneously, we consider a sample that includes only surviving firms that have never changed ownership over the sample period-we call it "balanced and constant ownership" sample.

Table XI shows the estimation results of (15) for our favorite TFP measure-TFPACF,Translog, using four different samples: the benchmark sample, balanced panel, constant ownership and balanced and constant ownership sample. We are most interested in the coefficient of the interaction

\footnotetext{
${ }^{12}$ Among the 142,717 firms in our merged patent-SIE sample, 20,737 of them have changed ownership, which account for $14.5 \%$ of the firms in the benchmark sample.
} 
Table X. Patenting and Production Performance: SOEs vs. POEs

\begin{tabular}{|c|c|c|c|c|c|c|}
\hline & $\lambda_{1}$ & (s.e.) & $\lambda_{2}$ & (s.e.) & $\lambda_{3}$ & (s.e.) \\
\hline \multicolumn{7}{|l|}{ Size } \\
\hline Output & $0.166^{* * *}$ & {$[0.007]$} & $0.084^{* * *}$ & {$[0.018]$} & $-0.047 * * *$ & {$[0.009]$} \\
\hline Value added & $0.167^{* * *}$ & {$[0.008]$} & $0.111^{* * *}$ & {$[0.021]$} & $-0.062^{* * *}$ & {$[0.012]$} \\
\hline Capital stock & $0.167^{* * *}$ & {$[0.007]$} & $0.201^{* * *}$ & {$[0.022]$} & $-0.108^{* * *}$ & {$[0.009]$} \\
\hline Employment & $0.160^{* * *}$ & {$[0.006]$} & $0.234^{* * *}$ & [0.018] & $-0.101^{* * *}$ & [0.009] \\
\hline \multicolumn{7}{|l|}{ Factor intensity } \\
\hline Capital-labor ratio & 0.007 & {$[0.007]$} & $-0.034^{* *}$ & {$[0.016]$} & -0.006 & {$[0.009]$} \\
\hline \multicolumn{7}{|l|}{ Productivity } \\
\hline Labor productivity & 0.006 & {$[0.005]$} & $-0.150^{* * *}$ & {$[0.016]$} & $0.055^{* * *}$ & {$[0.008]$} \\
\hline Solow Residual & 0.004 & {$[0.007]$} & $-0.104^{* * *}$ & {$[0.021]$} & $0.041^{* * *}$ & [0.010] \\
\hline OLS-FE & $0.048^{* * *}$ & {$[0.007]$} & $-0.053^{* * *}$ & {$[0.019]$} & 0.014 & [0.009] \\
\hline $\mathrm{TFP}^{A C F, C D}$ & $0.011^{* *}$ & {$[0.005]$} & $-0.091^{* * *}$ & {$[0.013]$} & $0.041^{* * *}$ & {$[0.007]$} \\
\hline $\mathrm{TFP}^{A C F, \text { Translog }}$ & $0.020^{* * *}$ & {$[0.006]$} & $-0.083^{* * *}$ & {$[0.015]$} & $0.035^{* * *}$ & {$[0.008]$} \\
\hline \multicolumn{7}{|l|}{ Other } \\
\hline New product (share) & $1.877^{* * *}$ & {$[0.270]$} & -0.105 & {$[0.538]$} & 0.270 & {$[0.322]$} \\
\hline Markup & -0.169 & {$[0.288]$} & 2.337 & {$[3.226]$} & 0.759 & {$[0.622]$} \\
\hline Export shipment & $0.431^{* * *}$ & {$[0.036]$} & $0.323^{* * *}$ & {$[0.074]$} & $-0.130^{* * *}$ & {$[0.043]$} \\
\hline
\end{tabular}

Table XI. SOEs vs. POEs: Sample Selection

\begin{tabular}{lllll}
\hline \hline \multirow{2}{*}{ Dep. Var. } & \multicolumn{4}{c}{ TFP ACF,Translog } \\
\cline { 2 - 5 } & $\begin{array}{l}\text { A. Benchmark } \\
\text { Sample }\end{array}$ & $\begin{array}{l}\text { B. Balanced } \\
\text { Panel }\end{array}$ & $\begin{array}{l}\text { C. Constant } \\
\text { Ownership }\end{array}$ & $\begin{array}{l}\text { D. Balanced and } \\
\text { Constant Ownership }\end{array}$ \\
\hline $\ln S$ & $0.020^{* * *}$ & $0.023^{*}$ & $0.015^{* *}$ & 0.011 \\
$($ s.e. $)$ & {$[0.006]$} & {$[0.014]$} & {$[0.007]$} & {$[0.007]$} \\
$S O E$ & $-0.083^{* * *}$ & $-0.135^{* * *}$ & - & - \\
$($ s.e. $)$ & {$[0.015]$} & {$[0.026]$} & - & - \\
$\ln S \times S O E$ & $0.035^{* * *}$ & $0.051^{* * *}$ & $0.054^{* * *}$ & $0.089^{* * *}$ \\
$($ s.e. $)$ & {$[0.008]$} & {$[0.014]$} & {$[0.014]$} & {$[0.027]$} \\
\hline Number of obs & 142717 & 26,310 & 121,980 & 19,620 \\
$R^{2}$ & 0.94 & 0.95 & 0.95 & 0.95 \\
\hline \hline
\end{tabular}

term $\ln (S) \times S O E$, which captures how the growth in patent is related to growth in TFP differently for SOEs compared to POEs. This coefficient is positive and significant at $1 \%$ level for all four samples examined. In addition, the coefficient is the highest for the most restricted sample (balanced and constant ownership sample), implying that it is "Grasp the Big" or "Strengthening the Big" rather than "Let Go of the Small" that drives the result. Using alternative TFP measures do not alter this results.

\section{B. The Impact of SOE Reform}

The results above suggests that SOEs are better than POEs in associating changes in innovation to productivity growth. However, analyses summarized by regression (15) and (16) do not address 
whether firm ownership has any causal effect on how innovation is transformed into productivity growth, since both patenting behavior and ownership status are not exogenously determined. To provide a clearer identification, we carry put two additional exercises. First, we use the nationwide SOE reform as a "natural experiment". An interesting fact is that before 2002, an average SOEs filed less patent applications than an average POEs. However, it surpassed POEs in 2003 and the gap has been widening ever since. Note that 1998-2002 is when the SOE reform took place. To investigate whether SOE reform has heterogeneous effect on the relationship between productivity growth depending on the firm's ownership status, we use the reform as an exogenous event and adopt a difference-in-difference (DID) estimation strategy. Our empirical specification is as follows:

$$
\begin{aligned}
\ln T F P_{i t}^{j}= & \phi_{1} \ln S_{i t}^{j}+\phi_{2} S O E_{i t}^{j}+\phi_{3} \text { Post_reform }_{t}+\phi_{4} \ln S_{i t}^{j} \times S O E_{i t}^{j}+\phi_{5} \ln S_{i t}^{j} \times \text { Post_reform } m_{t}+ \\
& \phi_{6} S O E_{i t}^{j} \times \text { Post_reform }{ }_{t}+\phi_{7} \ln S_{i t}^{j} \times S O E_{i t}^{j} \times \text { Post_reform }{ }_{t}+\mu_{i}+\gamma_{j, t}+\varepsilon_{i t}^{j},
\end{aligned}
$$

where Post_reform $t_{t}$ is an indicator variable equal to 1 for the post-reform period, i.e. $t \geq 2002$. SOE versus POE status (embodied by $S O E$ dummy) provides the first layer of the difference. And the before and after SOE reform (embodied by Post_reform dummy) provides the second layer of the difference.

Table XII shows results for the DID specification of equation (17), using TFP $\mathrm{TCF}^{A \text { Translog }}$ as the dependent variable for all four samples mentioned above. Besides similar results as in previous sections, the table shows that TFP is higher in post-reform period. The significantly positive coefficient of interaction term SOE $\times$ Post_reform indicates that the TFP of SOEs has been increasing faster than that of POEs after the SOE reform. After the reform, SOEs are catching up with POEs in terms of productivity. This finding is consistent with the main findings in Hsieh and Song (2015).

The coefficient of interest, $\phi_{7}$, which captures how productivity growth responds to changes in patent stock differently in the post-reform period relative to the pre-reform period in SOEs relative to POEs, is estimated to be positive but not significant for the benchmark sample and the constant ownership sample, but significant for the balanced panel and balanced and constant ownership panel. This finding implies that considering only the surviving firms (which are most likely large firms), SOE reforms significantly improves SOEs' ability to adapt new innovation to boost productivity compared with POEs. In other words, the reform not only allows SOEs to catch up with POEs in terms of the level of TFP-as emphasized in Hsieh and Song (2015) - but 
Table XII. The Role of SOE Reform

\begin{tabular}{lllll}
\hline \hline Dependent & \multicolumn{3}{c}{ TFP } \\
variable & A. Full & $\begin{array}{l}\text { B. Balanced } \\
\text { Panel }\end{array}$ & $\begin{array}{l}\text { C. Constant } \\
\text { Ownership }\end{array}$ & $\begin{array}{l}\text { D. Balanced and } \\
\text { Constant Ownership }\end{array}$ \\
\hline $\ln S_{i t}$ & $0.142^{* * *}$ & $0.137^{* * *}$ & $0.142^{* * *}$ & $0.127^{* * *}$ \\
$($ s.e. $)$ & {$[0.008]$} & {$[0.013]$} & {$[0.009]$} & {$[0.016]$} \\
$S O E_{i t}^{j}$ & $-0.182^{* * *}$ & $-0.223^{* * *}$ & - & - \\
$($ s.e. $)$ & {$[0.026]$} & {$[0.036]$} & - & - \\
Post_reform & \\
$($ s.e. $)$ & $0.258^{* * *}$ & $0.396^{* * *}$ & $0.251^{* * *}$ & $0.385^{* * *}$ \\
$\ln S_{i t} \times$ SOE $_{i t}^{j}$ & {$[0.013]$} & {$[0.019]$} & {$[0.013]$} & {$[0.021]$} \\
$($ s.e. $)$ & $0.036^{* * *}$ & $0.043^{* * *}$ & 0.025 & 0.046 \\
$\ln S_{i t} \times$ Post_reform $_{t}$ & {$[0.011]$} & {$[0.016]$} & {$[0.020]$} & {$[0.034]$} \\
$($ s.e. $)$ & $-0.015^{* * *}$ & $-0.038^{* * *}$ & $-0.015^{* *}$ & $-0.037^{* * *}$ \\
$S O E_{i t}^{j} \times$ Post_reform $_{t}$ & {$[0.006]$} & {$[0.008]$} & {$[0.006]$} & {$[0.008]$} \\
$($ s.e. $)$ & $0.110^{* * *}$ & $0.081^{* *}$ & $0.114^{* * *}$ & $0.105^{* *}$ \\
$\ln S_{i t} \times$ SOE $_{i t}^{j} \times$ Post_reform $_{t}$ & {$[0.024]$} & {$[0.035]$} & {$[0.029]$} & {$[0.041]$} \\
$($ s.e. $)$ & 0.005 & $0.029^{*}$ & 0.021 & $0.046^{* *}$ \\
\hline Number of obs & {$[0.012]$} & {$[0.015]$} & {$[0.014]$} & {$[0.020]$} \\
$R^{2}$ & 142,717 & 26,310 & 121,980 & 19,620 \\
\hline \hline
\end{tabular}

Note: All regressions control for firm and four-digit industry fixed effects.

also make them better firms in transforming innovation into within-firm productivity growth.

\section{SOEs and Innovation Quality}

The previous sections document a surprising finding that SOEs tend to be better at associating new patent with TFP growth than POEs. However, as discussed before not all patents are of the same quality. In this section, we differentiate patents by their types and investigate which type of patents SOEs are particularly good at adapting. As discussed in Section 2, an invention patent usually needs to meet higher and stricter requirement than the other two types of patent (utility model and design) in China, and is viewed in general with higher quality. We then redo all analysis in Section 5 for these three different types of patents individually. Detailed results are not reported here to save the space but are explained as below.

The observation that the elasticity of $\mathrm{TFP}^{A C F, \text { Translog }}$ with respect to patent stock is higher for SOEs is found to be particularly significant for utility model and design patents. While still positive, this elasticity is not significant when considering only the invention patents. Similarly, the before-and-after effect of switching ownership on this elasticity is also muted in the case of invention patents, while still significant in the case of utility model patent and design patent.Using balanced and constant ownership sample, we find that SOE reforms help to improve this elasticity for SOEs compared to its impact on POEs. The elasticities of $\mathrm{TFP}^{A C F, C D}$ with respect to patent stock, 
however, are significantly higher for SOEs for all three types of patent, and the before-and-after analysis also shows that switching ownership from being state-owned to private-owned is associated with lower TFP-patent elasticity in all three patent types. Overall, the above results indicate that SOEs are better than POEs in associating innovation with productivity growth, but they are more successful at this for patent with lower quality.

Why are TFP growth-patent elasticities higher for SOEs? Casual observations point to three potential explanations: the differential access to finance, subsidy and competition. Research has shown that SOEs have much easier access to the credit market, especially after the SOE reform, and receive more subsidies from the government (Song et al. (2011), Chang et al. (2015)). As shown in Panel (a) of Figure IV, in our merged data the leverage ratio of SOEs has been significantly higher than that of POEs for the entire sample period with the average ratio 0.69 for SOEs and 0.58 for POEs. Panel (b) demonstrates that an average SOE receives significantly more subsidies from the government than an average POE does, and the gap has been increasing over time, especially after the SOE reform. ${ }^{13}$ More funding and less financial constraint can allow firms to quickly take advantage of the knowledge capital and to convert new ideas into productivity improvement.

Figure IV. State Ownership, Financial Constraint and Subsidies

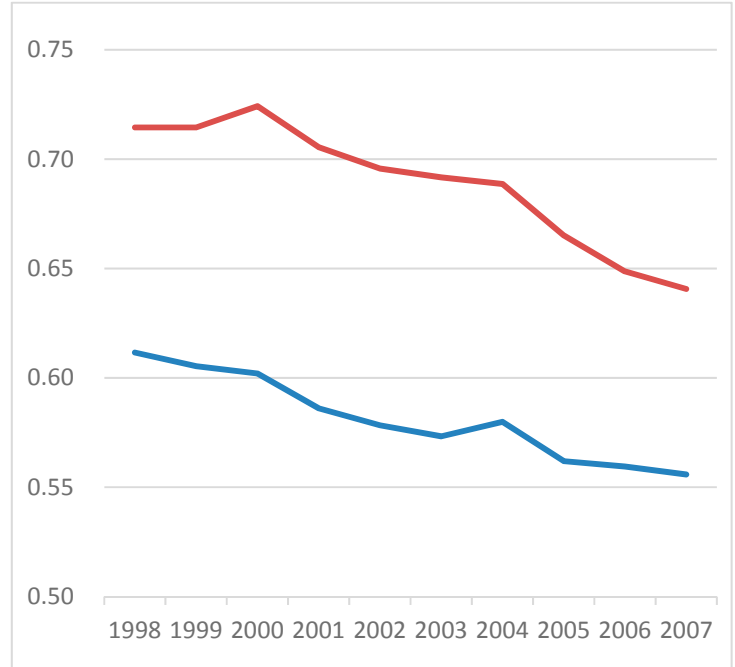

(a) Leverage

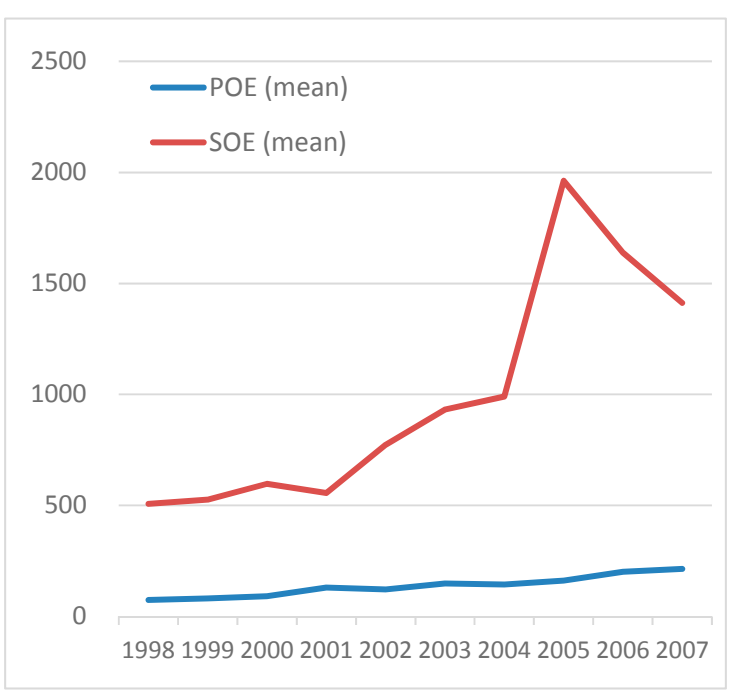

(b) Subsidy

Another characteristics that distinguish SOEs from POEs is the level of competition they face within the industry. Li, Liu and Wang (2015) document that after the reforms, SOEs are increas-

\footnotetext{
${ }^{13}$ Also noted in Aghion et al. (2015) is a similar pattern in terms of the percentage of SOEs and POEs that received positive subsidies. It rose from $14 \%$ in 1998 to $25 \%$ in 2007 by SOEs, compared to $8 \%$ in 1998 to $12 \%$ in 2007 by POEs.
} 
ingly concentrated in upstream industries with high monopoly power. As shown in Figure V, both central and local SOEs on average operate in sectors with much higher Herfindahl index than POEs. Evaluating the impact of these preferential government policies is beyond the goal of this paper but should be explored in the future.

Figure V. State Ownership and Competition (Herfindahl Index)

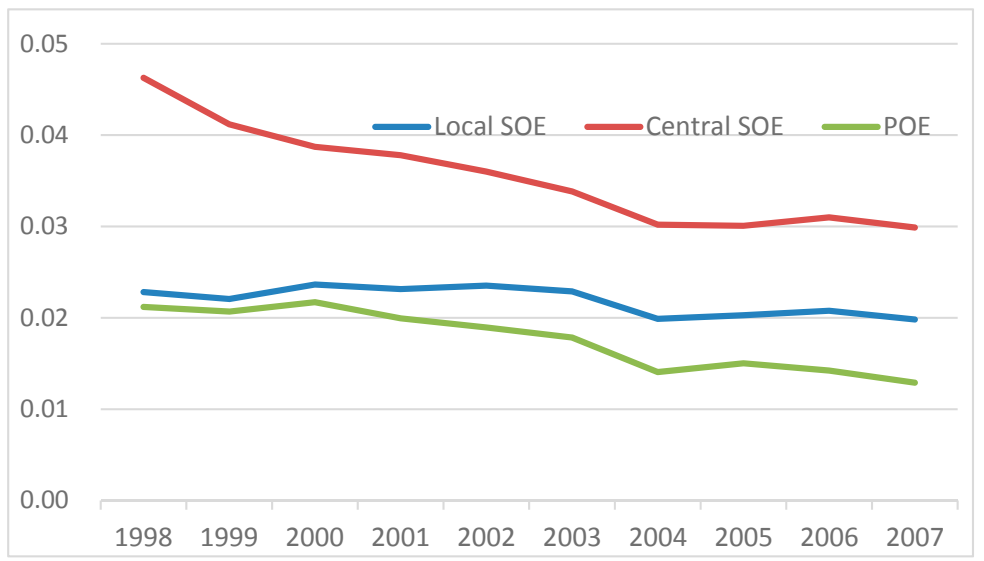

Notes: This figure present the average Herfindahl Index of the sector that a firm belongs to, dependent on the firm's ownership status.

\section{Conclusion}

Is firm patenting in China accompanied by real changes in firm production performance? This paper answers the question by constructing a unique dataset uniting detailed firm balance sheet data with patent application data for the period of 1998-2007. We find strong evidence that increases in patent stock are associated with increases in firm size (output, sales and employment), exports performance, and more interestingly, firm productivity and the revenue share of new products. The associated improvement in productivity is even higher than that found in prior study using U.S. data. Event studies based on first-time patentees also show similar effects following initial patent application. Contrary to conventional perception, we find that although SOEs on average have lower level of TFP, growth in patent stock is associated with significantly higher TFP growth among SOEs compared to their non-state peers, especially after the SOE reform occurred in late 1990s. However, further analysis reveals that this observation is limited to patents with less innovative content (i.e. utility model patents) and may be potentially linked to the preferential government policies enjoyed by SOEs particularly. The latter could reflect the preferential government policies enjoyed by SOEs. 


\section{Appendix A. Constructing Firm-Specific Markups}

Our construction of firm-specific markups closely follows De Loecker and Warzynski (2012). A firm $i$ at time $t$ produces output using the following production technology:

$$
Q_{i t}=Q_{i t}\left(K_{i t}, L_{i t}, \omega_{i t}\right)
$$

The only restriction we impose on $Q_{i t}$ to derive an expression of markup is that $Q_{i t}$ is continuous and twice differentiable with respect to its arguments.

Cost-minimizing producers consider the following Lagrangian function:

$$
\operatorname{Lag}\left(K_{i t}, L_{i t}, \lambda_{i t}\right)=r_{i t} K_{i t}+w_{i t} L_{i t}+\lambda_{i t}\left(Q_{i t}-Q_{i t}(.)\right)
$$

where $w_{i t}$ and $r_{i t}$ denote a firm's input cost for labor and capital, respectively. The first-order condition with respect to labor input is

$$
\frac{\partial L_{a g} i t}{\partial L_{i t}}=w_{i t}-\lambda_{i t} \frac{\partial Q_{i t}(.)}{\partial L_{i t}}=0
$$

where the marginal cost of production at a given level of output is $\lambda_{i t}$ as $\frac{\partial L a g_{i t}}{\partial Q_{i t}}=\lambda_{i t}$. Rearranging terms and multiplying both sides by $\frac{L_{i t}}{Q_{i t}}$, we can express the labor elasticity, $\theta_{i}$ as:

$$
\theta_{i}=\frac{\partial Q_{i t}(.)}{\partial L_{i t}} \frac{L_{i t}}{Q_{i t}}=\frac{1}{\lambda_{i t}} \frac{w_{i t} L_{i t}}{Q_{i t}}
$$

Define markup $\mu$ as the ratio of price over marginal cost, $\mu=\frac{P_{i t}}{\lambda_{i t}}$. Using this definition, we can rewrite equation $(21)$ as

$$
\theta_{i}=\mu_{i t} \frac{w_{i t} L_{i t}}{P_{i t} Q_{i t}}
$$

Based on equation (22), once the labor elasticity, $\theta_{i}$, is obtained from the production function estimation and the share of labor costs in total sales, $\frac{w_{i t} L_{i t}}{P_{i t} Q_{i t}}$, is measured from data, firm's markup can be constructed as follows:

$$
\mu_{i t}=\theta_{i t} \frac{P_{i t} Q_{i t}}{w_{i t} L_{i t}} .
$$




\section{Appendix B. The Analysis of Propensity-Score Matching}

Our difference-in-difference analysis hinges crucially on the compariability between patenting and nonpatenting firms. To guarantee the comparison is meaningful, we have to make sure the treatment group (patenting firms) and control group (nonpatenting firms) are similar in terms of the major firm characteristics. Propensity-Score Matching (PSM) method serves this propose. Here we lay out the PSM procedure as follows.

For each firm $i$, define the treatment $D_{i}=1$ if the firm applies for at least one patent, and zero otherwise. We run the following logit model to estimate the propensity score:

$$
\operatorname{Pr}\left(D_{i}=1 \mid X\right)=G(\text { size, age, industry dummy, year dummy) }
$$

where $X=\{$ size, age $\}$ and $G(z)=\exp (z) /(1+\exp (z))$.

For firm $i$ in the treatment group, we define $p_{i}(x)=\operatorname{Pr}\left(D_{i}=1 \mid X=x\right)$. Under the common support condition, we have $0<p_{i}(x)<1$. We then take the nearest matching approach to pick the "matched" non-treated firm $j$ for a treated firm $i$, based on the following criteria:

$$
\left\|p_{i}-p_{j}\right\|=\min _{k \in\{D=0\}}\left\|p_{i}-p_{k}\right\|
$$




\section{References}

[1] Aghion, Philippe, Nick Bloom, Richard Blundell, Rachel Griffith and Peter Howitt (2005), "Competition and Innovation: An Inverted-U Relationship", Quarterly Journal of Economics, 120(2): 701-728.

[2] Aghion, Philippe, Jing Cai, Mathias Dewatripont, Luosha Du, Ann Harrison and Patrick Legros (2015), "Industrial Policy and Competition", American Economic Journal: Macroeconomics 7(4): 1-32.

[3] Ackerberg, Daniel, Kevin Caves, and Garth Frazer (2015), "Identification Properties of Recent Production Function Estimators", Econometrica, 83(6): 2411-2451.

[4] Balasubramanian, Natarajan and Jagadeesh Sivadasan (2011), "What Happens When Firms Patent? New Evidence From U.S. Economic Census Data", Review of Economic Statistics, 93(1): 126-146.

[5] Bloom, Nick, and Van Reenen J (2002), "Patents, Real Options and Firm Performance". Economic Journal, 112:97-116.

[6] Borensztein, Eduardo and Jonathan Ostry (1996), "Accounting for China's Growth Performance". American Economic Review, 86(2): 224-2228.

[7] Bloom Nick, Mark Schankerman and John Van Reenen (2013), "Identifying Technology Spillovers and Product Market Rivalry", Econometrica, 81(4): 1347-1393.

[8] Brandt, Loren, Johannes Van Biesebroeck and Yifan Zhang (2012), "Creative Accounting or Creative Destruction? Firm-Level Productivity Growth in Chinese Manufacturing", Journal of Development Economics, 97:339-351.

[9] Brandt, Loren, Johannes Van Biesebroeck and Yifan Zhang (2014), "Challenges of Working With the Chinese NBS Firm-Level Data", China Economic Review, 30: 339-352.

[10] Brandt, Loren, Chang-tai Tsieh, and Xiaodong Zhu (2008), "Growth and Structural Transformation in China", pp. 683-729, in "China's Great Economic Transformation" edited by Loren Brandt and Thomas G. Rawski, Cambridge University Press.

[11] Brandt, Loren, and Xiaodong Zhu (2010), "Accounting for China's Growth", Working Paper DP No. 4764, IZA. 
[12] Chang, Chun, Kaiji Chen, Daniel Waggoner and Tao Zha (2015), "Trends and Cycles in China's Macroeconomy," NBER Macroeconomics Annual 2015, 30.

[13] De Loecker, Jan, and Frederic Warzynski (2012) "Markups and Firm-Level Export Status", American Economic Review, 102:2437-71.

[14] Du, Luosha, Ann Harrison and Gary Jefferson (2012). "Testing for Horizontal and Vertical Foreign Investment Spillovers in China, 1998-2007", Journal of Asian Economics 23(3): 234243.

[15] Farre-Mensa, Joan and Alexander Ljungqvist (2013), "Do Measures of Financial Constraints Measure Financial Constraints?" NBER Working Paper No. 19551.

[16] Hall, Bronwyn, Adam Jaffe and Manuel Trajtenberg (2001), "The NBER Patent Citations Data File: Lessons, Insights and Methodological Tools", NBER working paper No. 8498.

[17] Hall, Bronwyn, Adam Jaffe and Manuel Trajtenberg (2005) "Market Value and Patent Citations", Rand Journal of Economics, 36, 16-38.

[18] Hsieh, Chang-Tai, and Zheng Song (2015), "Grasp the Large, Let Go of the Small: The Transformation of the State Sector in China", forthcoming, Brookings Papers on Economic Activity.

[19] Hu, Albert G. and Gary H. Jefferson (2009), "A Great Wall of Patents: What is Behind China's Recent Patent Explosion?" Journal of Development Economics, 90: 57-68.

[20] Klette, Jakob and Samuel Kortum (2004), "Innovating Firms and Aggregate Innovation", Journal of Political Economy, 112(5): 986-1086.

[21] Levinsohn, J. and A. Petrin (2003), "Estimating Production Functions Using Inputs to Control for Unobservables", Review of Economic Studies 317-342.

[22] Li, Xi, Xuewen Liu, and Yong Wang (2015), “ A Model of China's State Capitalism”, Hongkong University of Science and Technology, Working Paper.

[23] Liu, Qing, Ruosi Lu, Yi Lu, and Tuan Anh Luong (2014), "Is Free Trade Good or Bad for Innovation?", National University of Singapore, mimeo. 
[24] Olley, Steven and Ariel Pakes (1996), "The Dynamics of Productivity in the Telecommunications Equipment Industry", Econometrica, 64(6): 1263-1297.

[25] Song, Zheng, Kjetil Storesletten and Fabrizio Zilibotti (2011), "Growing Like China," American Economic Review 101:202-241.

[26] Thomas Reuters Report (2014), "China's IQ: Trends in Patenting and the Globalization of Chinese Innovation".

[27] Wei, Shang-jin, Zhuan XIe, and Xiaobo Zhang (2016) "From 'Made in China' to 'Innovated in China': Necessity, Prospect, and Challenges", Journal of Economic Perspectives, forthcoming.

[28] World Bank Report (2013), “ China's Growth through Technological Convergence and Innovation? in China 2030: Building a Modern, Harmonious, and Creative Society".

[29] Zhu, Xiaodong (2012), "Understanding China's Growth: Past, Present and Future", Journal of Economic Perspective, 26(4): 103-124. 